Research paper

\title{
Risk information, risk salience, and adolescent sexual behavior: Experimental evidence from Cameroon ${ }^{\text {th }}$
}

\author{
Pascaline Dupas $^{\mathrm{a}, *}$, Elise Huillery ${ }^{\mathrm{b}}$, Juliette Seban ${ }^{\mathrm{c}}$ \\ a Stanford University, NBER, CEPR, BREAD and J-PAL, United States \\ ${ }^{\mathrm{b}}$ University of Paris-Dauphine and J-PAL, France \\ c Sciences Po LIEPP, France
}

\section{A R T I C L E I N F O}

\section{Article history:}

Received 19 June 2017

Received in revised form 5 October 2017

Accepted 5 October 2017

Available online 20 November 2017

\section{Keywords:}

HIV

Teen pregnancy

Risk perceptions

Experiment

\begin{abstract}
A B S T R A C T
Why do teenagers take risks and what can be done about it? Results from a randomized experiment conducted with teenage schoolgirls in Cameroon suggest that risky sexual behavior responds to both risk mitigation information and risk salience. We find that sexual education sessions delivered to students either by specialized consultants over an hour, or through regular school staff over multiple weeks, led to improved health knowledge and decreased teen pregnancy rates in the following 9-12 months. A one- time, one-hour group-administered questionnaire on HIV and sexual behavior had an equally large impact on teen pregnancy without improving knowledge - it instead made the risks more salient and changed subjective beliefs. We find no effects among urban schoolgirls, who are more exposed to information and experience much lower rates of teenage pregnancy under the status quo.
\end{abstract}

(c) 2017 Elsevier B.V. All rights reserved.

\section{Introduction}

Every day young people engage in risky behaviors, including teen drinking and driving, smoking, drug use, criminal activity, and unprotected sex. Future costs of these behaviors are often immense. For example, unprotected sex presents the dual risk of unwanted pregnancy and HIV infection. These risks are disproportionately borne by young women. Women aged 15-24 years are at particularly high risk of HIV infection, accounting for $20 \%$ of new HIV infections among adults globally in 2015, despite accounting for just $11 \%$ of the adult population. These same young women are also at risk of early, unwanted pregnancy, and complications during pregnancy and childbirth are the second cause of death for 15-19 year-

\footnotetext{
is The study protocol was approved by the IRBs of UCLA (G09-12-047-01), MIT (0911003549), and Comité National d'Ethique du Cameroun (158-CNESE-09). We thank IRESCO for their collaboration, in particular Jean-Paul Tchupo, Gédéon Yomi, Eugène Njakou, Tiburce Nijama, and Odile Koumaga for outstanding project management, and Blanche Djofang and Méline Dawah who implemented the consultant interventions. We are grateful to Mathilde Emeriau and Julie Berthet-Valdois for outstanding research assistance, and for helpful and constructive comments we thank Rachel Glennerster, Odyssia $\mathrm{Ng}$, the editor, and two anonymous referees. The funding for this study was provided by the Agence Française de Développement (AFD), the William et Flora Hewlett Foundation, and the Institut de Recherche pour le Développement (IRD) (Grant 2008-2165 for the « DEMTREND " project). We thank them, without implicating them, for making this study possible. Dupas gratefully acknowledges the support of the NSF (award number 1254167) and Huillery gratefully acknowledges the support of the CEPREMAP. This randomized trial is registered in The American Economic Association's registry for randomized controlled trials under RCT ID AEARCTR-0000609

* Corresponding author.

E-mail addresses: pdupas@stanford.edu (P. Dupas), elise.huillery@dauphine.fr (E. Huillery), juliette.seban@sciencespo.fr (J. Seban).
} 
old girls globally. ${ }^{1}$ What determines their behavior and what policy tools, if any, can help them successfully avoid these risks? In economic models, risky behaviors are the consequence of ignorance or time discounting (see Levine, 2001 for an overview). These models assume that teenagers' decisions are made on the basis of a comparison of the benefits and costs of the alternatives. In this view, teenagers engage in risky behavior either because they ignore the "prices" (consequences of these behaviors), or because the benefits incurred at the moment are valued more highly than the potential high costs that may be incurred sometime in the future (Leibowitz et al., 1986). An important implication is that teens' behavior can be changed by increasing awareness about the risks and their consequences for the future, or by decreasing the present cost of safe behaviors.

This paper tests the hypothesis that the behavior of adolescents responds to risk information and risk salience. We consider one type of risky behavior: risky sex, in one context: Cameroon. We focus on adolescent girls, who face a particularly high risk burden as mentioned above. Given that the majority of youths, in Cameroon as in most of the world, are in school until age 15, an obvious way to provide risk information to youths is through schools. And indeed, most countries have adopted a national sexual education curriculum that teachers are required to integrate in their classes. However, evidence on the effectiveness of school-based sex education is mixed: systematic reviews of the effects of HIV education programs in SubSaharan Africa reveals great heterogeneity in effectiveness (Paul-Ebhohimhen et al., 2008; Gallant and Maticka-Tyndale, 2004). de Walque (2014) provides an overview of school-based sex education programs to prevent risky sexual behavior and points to the difficulty in translating knowledge into concrete behavioral changes. Behrman and Kohler (2012) make clear that the evidence on the efficacy of prevention intervention is limited.

One important question that emerges from the literature to date concerns how to present risk information. Risk levels are typically thought of by scientists as prevalence or incidence rates, but probabilities may not be as palatable to a more general audience: what does a $0.08 \%$ HIV transmission risk-per-exposure represent ${ }^{2}$ When asked about prevalence rates or probabilities, survey respondents typically vastly overstate risk. For example, Delavande and Kohler (2017) show that individuals in Malawi overestimate the risk associated with having multiple partners relative to only one partner. In such context, providing statistics from medical studies may well be counter-productive and increase rather than decrease risk taking. Given this, risk information often takes the form of a simple messages: "abstain or be faithful", "smoking kills", "this well's arsenic contamination level is above the approved maximum." ${ }^{3}$ Yet such simple messages, which aim for complete risk avoidance, may be too prescriptive and not informative enough to allow individually optimal risk mitigation responses (Dupas, 2011).

A second question concerns the way to engage youths in critically assessing the risks they face. Despite the fact that teacher-led interventions are logistically easier to implement, they can have some limitations because of teachers' status in relation to pupils or their discomfort in discussing sensitive topics such as sexually transmitted infections and pregnancy, or sexual behavior in general (Ross et al., 2006). An observational study conducted over 15 sub-Saharan countries between 2007 and 2010 found a very large gap in knowledge between students and their teachers, concluding that teachers lack either motivation or adequate teaching methods (or both) to effectively deliver HIV risk and sexual education (UNESCO, 2011). What are possible alternatives to teachers? One (expensive) option could be outside professionals. Dupas (2011) found that a 45-min session delivered by an outside facilitator with a focused message on the heightened risk of HIV faced by girls having sex with older partners was effective at reducing unprotected sex among adolescent girls in Kenya, while the regular HIV and sexual education curriculum delivered by trained teachers and focusing on abstinence and faithfulness promotion had no impact. It is unclear what part of this difference comes from the specific relative risk message, and what part could come fom the fact that the trained professionals were better equipped to discuss sensitive issues than teachers. Another alternative to teachers is technology: online sex education and health programs, whereby youth can ask questions by SMS, have been tried, though evidence of their impacts is mixed (Chong et al., 2013; Jamison et al., 2013). More promising evidence suggests that interactive ways of communicating information (such as feedback to guesses about facts such as HIV prevalence by age groups) can be more effective at increasing knowledge than providing the same information through a brochure (Datta et al., 2015). How much of this comes from the fact that asking participants to engage with the information increases its salience? At the extreme, can a simple questionnaire administered in class about HIV risk and own plans to avoid it be sufficient to make risk salient and spur adolescents to actively think through the types of behavior they want to avoid?

We use a field experiment conducted with teenage girls in 318 junior high schools in Cameroon to study, within one context, how the type of risk information being provided and the delivery method (teacher, outside professional or questionnaire) affect adolescents knowledge, perceived risks and behavior. According to UNAIDS, Cameroon is the West and Central African country with the highest rate of HIV prevalence at $4.5 \%$ of the 15-49 population in 2015 (5.3\% among women and $3.7 \%$ among men). We randomized HIV and sexual education interventions that differed in their delivery mechanism and intensity, as well as content, across schools. In each school, one eighth grade class was targeted for the study.

\footnotetext{
${ }^{1}$ WHO factsheet, last accessed 18 November 2016 at: http://www.who.int/mediacentre/factsheets/fs364/en/.

2 Risk-per-exposure is the risk of HIV infection when an uninfected person has unprotected sex with an infected partner.

3 See Dupas (2011) on HIV risk information in Kenya, Delavande and Kohler (2017) on HIV risk information in Malawi, and Bennear et al. (2013) on arsenic risk communication in Bangladesh.
} 
We consider four interventions. The first (In-Class Quiz) was completely "hands-off", and not labeled as an educational intervention: students were simply asked to fill in an anonymous questionnaire with questions on HIV as well as on their own sexual behavior and that of their peers. The questionnaire took about one hour to go through, including the time to introduce it. The In-Class Quiz was a group-administered questionnaire and did not provide students with direct information, but required that students think actively about risk levels (e.g. they were asked to estimate the HIV prevalence rate in Cameroon) and their own behavior. ${ }^{4}$

The other three interventions were clearly labeled as HIV education programs. Two of them consisted of general information on HIV prevention methods (abstinence, faithfulness and condom use) and the average HIV prevalence at the national level (the "basic message"). A third one mimicked the "sugar daddy risk information" first proposed in Dupas (2011) and included, on top of the basic message, detailed information on HIV prevalence disaggregated by gender and age group and a special module on cross-generational relationships, locally known as relationships with "sponsors", and their contribution to the spread of HIV. The difference between the two "basic message" interventions is that one was delivered through regular school staff which received special training (Teacher Training), while the second one was delivered by an outside consultant who did a special visit to the school to deliver the message (Consultant). The intervention that included the sugar daddy module was also delivered by an outside consultant (Consultant + ). Both interventions by consultants lasted approximately one hour.

We measure the impacts of the four interventions separately, as well as the impacts of the education interventions combined with the In-Class Quiz, using self-reported outcomes measured after 9-12 months among a random subset of girls in the targeted classes $(\mathrm{N}=3154)$.

We find that all interventions were successful at reducing the incidence of teenage pregnancy during our follow-up period. The magnitude of the effects are relatively large, with an average drop of $2.9 \%$ points in the likelihood of having started childbearing at the time of the endline, off a mean in the control group of $9.5 \%$, thus a $30 \%$ reduction. This magnitude is in line with the $28 \%$ decrease in teen pregnancy in Dupas (2011). The most surprising results is that the most hands-off intervention, the In-Class Quiz, was successful, by itself, at reducing the incidence of unprotected sex and hence pregnancy in the following 12 months. The effect of the In-Class Quiz does not amplify the effects of the other interventions however when implemented jointly, the effect is not larger than that of either education intervention alone, suggesting that the Quiz and the education interventions are perfect substitutes for each other. Finally, the special message on risks associated with older men did not make a difference compared to the basic message.

Turning to mechanisms, we find that the interventions increased the likelihood that girls report adopting a clear, onepronged strategy against HIV: abstinence. When asked what their plan is to avoid HIV infection in the coming year, girls in the intervention arms were less likely to report condom use - a strategy that is quite common but not perfect, since close to a third of sexually active girls report not using a condom at their first intercourse - and more likely to report abstinence, and to report only abstinence. It is thus possible that the interventions worked in part by making girls home in on a concrete plan with regards to their future sexual behavior. This would be consistent with the literature suggesting that plan-making helps people overcome several psychological barriers to follow through (Gollwitzer and Sheeran, 2006). The hypothesized mechanism behind this is the following: forming a concrete plan means forming an association between a specific future situation and the desired behavior (e.g., "When the opportunity to have sex arrives, I will react to it [this way].")

Importantly, the mechanism through which the interventions helped girls adopt a clear and simple strategy against HIV differs between the In-Class Quiz and the education interventions. The In-Class Quiz led participants to revise upward their subjective beliefs about risk, while the other interventions improved knowledge without changing risk perceptions. This is in a context where, as documented in the previous literature, individuals overestimate the HIV infection risks associated with sexual activity to start with. The In-Class Quiz, which brought up HIV risk without providing any information, seems to have worked as a nudge attracting girls' attention on risks and further increasing the perceived costs of unsafe sex. In contrast, the education interventions did not change perceived risks (it did not make them even more pessimistic as the Quiz, but it did not bring them much closer to reality either), but it did affect girls' knowledge about HIV transmission and prevention. In our context, these two mechanisms (change in subjective beliefs about risk and change in knoweldge) turn out to be equally effective at changing girls' plans and behaviors.

The finding that the simple In-Class Quiz influenced beliefs and behavior confirms existing evidence of survey effects. This phenonemon is well-known in marketing research and is coined the "question-behavior effect" (see Dholakia, 2010 for a review). For instance, Chandon et al. (2005) show that being surveyed inflates the association between intentions and behavior: the correlation between latent intentions and purchase behavior is $58 \%$ greater among surveyed consumers than it is among similar nonsurveyed consumers. This effect had been rarely explored outside of purchase behaviors until recently. In the health domain, Zwane et al. (2011) describe three health studies in which subjects in lower income countries were randomly assigned to receive a survey about health. They find that being surveyed regularly about health levels in the household increased the use of water treatment products as well as take-up of medical insurance. ${ }^{5}$ In a different context

\footnotetext{
${ }^{4}$ We use the definition of "group-administered questionnaire" from the Research Methods Knowledge base: "A sample of respondents is brought together and asked to respond to a structured sequence of questions. [...] each respondent is handed an instrument and asked to complete it while in the room." (see https://www.socialresearchmethods.net/kb/survtype.php, last accessed 6 September 2017).

${ }^{5}$ They also report on two microlending studies in which being surveyed had no effect on borrowing behavior, however
} 
(the overdraft market in the US), Stango and Zinman (2011) find surveys about overdraft fees can successfully make the issue salient to people and affect behavior: people are less likely to incur a fee in the month following a survey, and the effect increases with repeated exposure to surveys. Bidwell et al. (2016) also find that being surveyed in depth about one's political views results in increased general political knowledge. Our results add to this nascent literature and indicate that such priming or salience effects of surveys can be large even with a one-time survey, and can be large for teenagers, a population of particular interest in the case of risky sexual behavior, and whose behavior is often described as particularly short-sighted (Gruber, 2001).

Our findings also suggest links between the "planning prompt" psychology literature mentioned above and the "questionbehavior" effect literature in marketing. The In-Class Quiz does not only make risks associated with sexual behaviors more salient, otherwise it would likely not have the type of fairly sustained impacts we see. Instead, the survey makes these risks salient and acts in part as a prompt to make a plan, so the impact could be longer lasting since the plan once formed can stick. In the health domain, Milkman et al. (2011) show that mailings informing people of where and when they can get a free flu shot increase take-up rate more if the mailing includes a prompt to write down the date one plans to get vaccinated on. In our case, the In-Class Quiz did not specifically ask teenagers to write down their own personal anti-HIV plan, but it did ask them to write down what they thought were the behaviors that can help prevent HIV infection, and it did ask them, right after that, to report on their own behavior. By exposing gaps between desired and actual behavior, the In-Class Quiz may have acted as a planning prompt.

A shortcoming of our study is that we have no biomarker data on infection with sexually transmitted infections (STIs) in our study sample. Our only "biological" outcome is pregnancy, but this may not be a perfect proxy for risky sexual behavior. Duflo et al. (2015) show that programs that reduce pregnancy rates may have no effect on STIs, and programs that may reduce STIs may have no detectable effects on pregnancy rates. What's more, our data on sexual behavior data is self-reported, and therefore possibly subject to reporting biases. More studies using biological outcomes should be carried out to fill this gap.

The paper is organized as follows. Section 2 presents the background on HIV education in Cameroon and the experimental design. Section 3 presents our data, outcomes of interest and empirical strategy. Section 4 present the results on exposure to HIV education and knowledge, dropout and pregnancy, and sexual behavior. Section 5 concludes.

\section{Background and experimental design}

\subsection{Background on HIV, teenage sexual behavior and sex education in Cameroon}

HIV Prevalence in Cameroon UNAIDS estimates that 1.8-2.4 million people were newly infected with HIV in 2015. The great majority of these new cases were in sub-Saharan Africa. Canning (2006) shows that promoting AIDS treatment in resource-constrained countries comes at a huge cost in terms of avoidable deaths that could be prevented through interventions that would substantially lower the scale of the epidemic. At the onset of this project in 2009, Cameroon was the country with the highest rate of HIV prevalence in the Central and West Africa Region, at 5.3\% of the 15-49 population (UNAIDS, 2010). By 2011, this rate had gone down to 4.3\% according to the latest Demographic and Health Survey, but this average masks important differences by gender. Indeed, the principal mode of transmission of HIV in Cameroon is heterosexual contact, and as in most of sub-Sarahan Africa, HIV prevalence is significantly higher for women than for men, at $5.6 \%$ vs $2.9 \%$. The breakdown by age and gender group is presented in Fig. 1. HIV prevalence is more than five times higher among women below the age of 24 than among men below 24 . This may be largely attributed to girls becoming sexually active at a younger age as well as physiological differences that make male-to-female transmission more likely than femaleto-male transmission (Bertozzi et al., 2006). In 2006, 14\% of girls between 15 and 19 years had their first sexual intercourse before the age of 14 in Cameroon (WHO, 2008).

HIV Knowledge and Sexual Behavior Among Teenagers Column 1 of Table 1 presents summary statistics on selfreported sexual behavior at the onset of the study (Jan-Feb 2010). The data come from the In-Class Quiz, which was digitized for a random subset of girls who had filled it. Quiz respondents were just above 15 years old on average. Just over $22 \%$ reported being sexually active. The use of condoms is widespread: $82 \%$ of sexually active girls declared having ever used a condom. The average number of partners in the last 12 months, if any, is two.

Awareness about HIV is almost universal (99\% declared they heard about HIV). However, knowledge on transmission is quite poor: Only $37 \%$ know that mosquitoes do not transmit HIV, and while a majority (55\%) mention condoms (unprompted) as a means to prevent HIV infection, only 39\% think that condoms are very effective at preventing HIV infection when used correctly. As in Dupas (2011), less than a third of girls are aware that men above 25 have a higher chance of having HIV than men below 25, and virtually none of them consider careful partner choice as a strategy to avoid HIV infection. Despite this being a sample of schoolgirls, some report having ever been pregnant (3.4\%) and 1.6\% are already married.

Column 2 of Table 1 shows the same variables collected at endline, for girls in the control group. As girls in the control group look similar to those who took the In-Class Quiz at baseline (see below in Section 3.2,), the changes from column 1 to column 2 provide some sense of the transformation in sexual behavior over the time period of the study, absent any specific intervention. Note that the way the information was elicited across the two columns varies as the In-Class Quiz was group-administered while the endine information comes from both face-to-face administration and self-administration (see Section 3.1). We find no major difference in variable means depending on endline survey administration mode, except, unsurprisingly, for the most sensitive outcomes (condom use, which is four percentage points higher in face-to-face inter- 


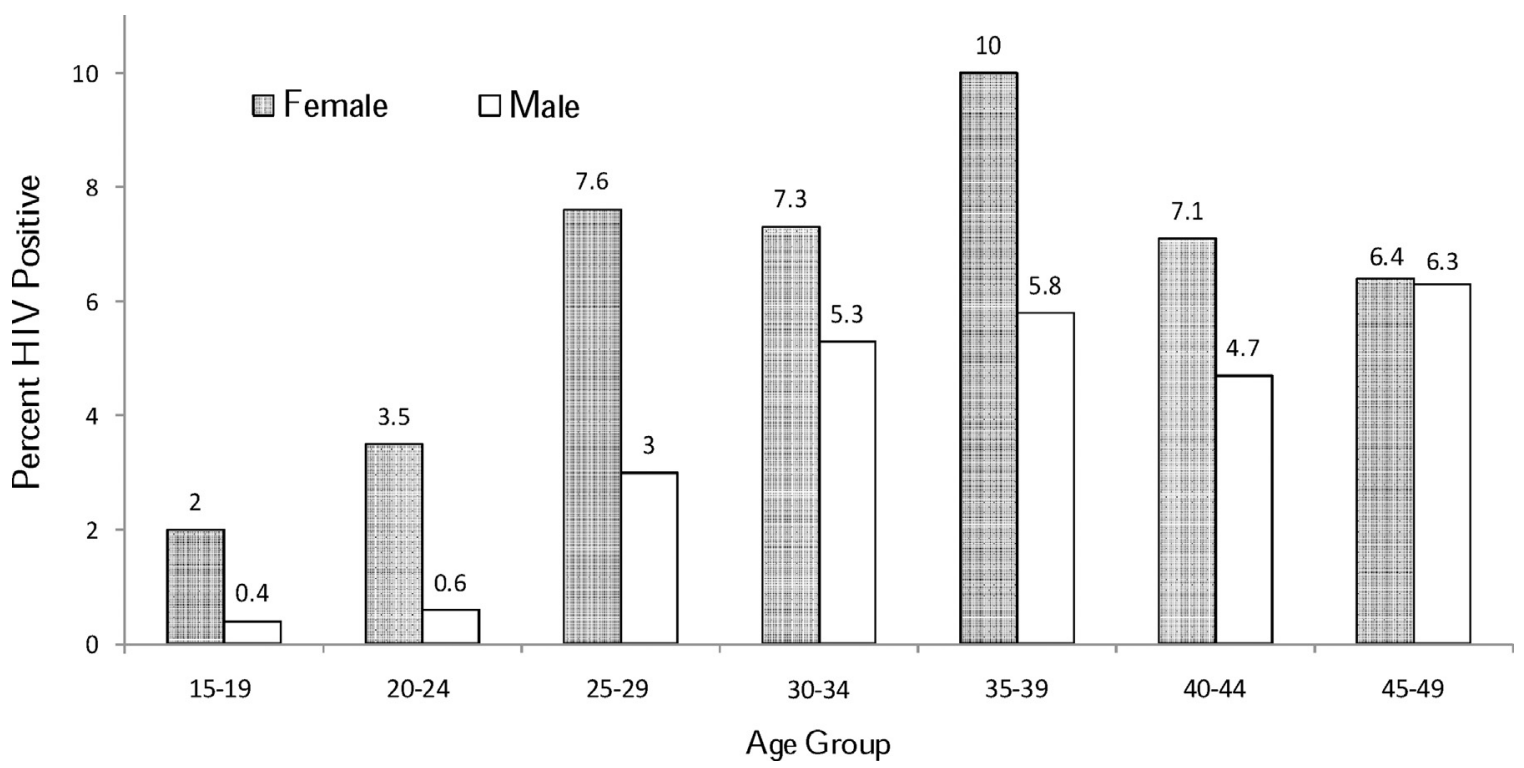

Fig. 1. 2011 HIV Prevalence in Cameroon, by Gender and Age Group.

Source: Cameroon DHS 2011 http://www.measuredhs.com/pubs/pdf/PR16/PR16.pdf.

Table 1

Summary Statistics: Teenage Sexual Behavior over Study period.

\begin{tabular}{|c|c|c|c|c|}
\hline & \multicolumn{2}{|l|}{ (1) } & \multicolumn{2}{|l|}{$(2)$} \\
\hline & \multicolumn{2}{|c|}{ Baseline In-Class Quiz (Weeks 4-5, 2010) } & \multicolumn{2}{|c|}{$\begin{array}{l}\text { Endline Control Group Only } \\
\text { (Weeks 4-17, 2011) }\end{array}$} \\
\hline & Mean [Std. Dev.] & Obs & Mean [Std. Dev.] & Obs \\
\hline Age in years & $\begin{array}{l}15.487 \\
{[1.634]}\end{array}$ & 1467 & $\begin{array}{l}16.77 \\
{[1.648]}\end{array}$ & 361 \\
\hline Ever heard of HIV & $\begin{array}{l}0.991 \\
{[0.093]}\end{array}$ & 1493 & $\begin{array}{l}1.000 \\
{[0]}\end{array}$ & 348 \\
\hline Knows mosquitoes do not transmit HIV & $\begin{array}{l}0.372 \\
{[0.483]}\end{array}$ & 1483 & $\begin{array}{l}0.44 \\
{[0.497]}\end{array}$ & 348 \\
\hline Mentions condoms as HIV prevention method & $\begin{array}{l}0.549 \\
{[0.498]}\end{array}$ & 1492 & $\begin{array}{l}0.819 \\
{[0.386]}\end{array}$ & 348 \\
\hline Thinks condoms are very effective & $\begin{array}{l}0.394 \\
{[0.489]}\end{array}$ & 1479 & $\begin{array}{l}0.289 \\
{[0.454]}\end{array}$ & 343 \\
\hline Knows older men are riskier partners in terms of HIV & $\begin{array}{l}0.311 \\
{[0.463]}\end{array}$ & 1487 & $\begin{array}{l}0.391 \\
{[0.489]}\end{array}$ & 348 \\
\hline Mentions careful partner choice as HIV prevention method & $\begin{array}{l}0.001 \\
{[0.037]}\end{array}$ & 1492 & $\begin{array}{l}0.023 \\
{[0.15]}\end{array}$ & 348 \\
\hline Ever had sex & $\begin{array}{l}0.222 \\
{[0.416]}\end{array}$ & 1488 & $\begin{array}{l}0.379 \\
{[0.486]}\end{array}$ & 367 \\
\hline If ever had sex: Ever used a condom/Used a condom at first sex & $\begin{array}{l}0.822 \\
{[0.383]}\end{array}$ & 332 & $\begin{array}{l}0.724 \\
{[0.449]}\end{array}$ & 123 \\
\hline Number of partners in last 12 months, if any & $\begin{array}{l}1.959 \\
{[2.731]}\end{array}$ & 217 & $\begin{array}{l}1.253 \\
{[0.595]}\end{array}$ & 99 \\
\hline Ever pregnant & $\begin{array}{l}0.034 \\
{[0.181]}\end{array}$ & 1479 & $\begin{array}{l}0.095 \\
{[0.294]}\end{array}$ & 367 \\
\hline Ever married & $\begin{array}{l}0.016 \\
{[0.127]}\end{array}$ & 1471 & $\begin{array}{l}0.022 \\
{[0.146]}\end{array}$ & 367 \\
\hline Age of the current (In-Class Quiz)/last (Endline) partner, if any & $\begin{array}{l}19.914 \\
{[3.971]}\end{array}$ & 269 & $\begin{array}{l}21.221 \\
{[2.983]}\end{array}$ & 95 \\
\hline Ever pregnant but did not want to get pregnant & & & $\begin{array}{l}0.075 \\
{[0.263]}\end{array}$ & 348 \\
\hline
\end{tabular}

Notes: Data from In-Class Quiz administered at baseline for a random subset, and endline survey. In-class Quiz was a self-filled, group-administered questionnaire (see details in text). 
318 schools from 3 regions

For each school:

- 1 grade 8 class sampled for intervention and end line survey $=318$ classes

- 10 girls sampled in that class for endline survey (or all girls if the class contains less than 10 girls)

$$
=>3154 \text { (2907) girls }
$$

\begin{tabular}{|c|c|c|c|c|c|c|c|}
\hline \multicolumn{2}{|c|}{ Status Quo } & $\begin{array}{r}\text { Teacher } \\
A B C \text { mess } \\
\text { by a } \\
80 \\
801(\end{array}$ & $\begin{array}{l}\text { ing }(\mathrm{TT}) \\
\text { delivered } \\
\text { cher } \\
\text { ols } \\
\text { girls }\end{array}$ & $\begin{array}{r}\text { Consu } \\
A B C \text { mess } \\
\text { by ac } \\
79 \\
773(\end{array}$ & $\begin{array}{l}\text { (C) } \\
\text { delivered } \\
\text { ultant } \\
\text { ols } \\
\text { girls }\end{array}$ & \multicolumn{2}{|c|}{$\begin{array}{c}\text { Consultant Plus }(\mathrm{C}+) \\
\text { ABC }+ \text { sugar daddy } \\
\text { delivered by a consultant } \\
79 \text { schools } \\
779(719) \text { girls }\end{array}$} \\
\hline Control & Q & TT & QTT & C & $\mathrm{dC}$ & $\frac{1}{C+}$ & $Q C+$ \\
\hline No Quiz & Quiz & No Quiz & Quiz & No Quiz & Quiz & No Quiz & Quiz \\
\hline 40 schools & 40 schools & 40 schools & 40 schools & 40 schools & 39 schools & 39 schools & 40 schools \\
\hline $\begin{array}{c}403(368) \\
\text { girls }\end{array}$ & $\begin{array}{c}398(355) \\
\text { girls }\end{array}$ & $\begin{array}{c}401(380) \\
\text { girls }\end{array}$ & $\begin{array}{c}400(369) \\
\text { girls }\end{array}$ & $\begin{array}{c}383(353) \\
\text { girls }\end{array}$ & $\begin{array}{c}390(363) \\
\text { girls }\end{array}$ & $\begin{array}{c}382(354) \\
\text { girls }\end{array}$ & $\begin{array}{c}397(365) \\
\text { girls }\end{array}$ \\
\hline
\end{tabular}

Fig. 2. Experimental Design.

Notes: Sample size $\mathrm{X}(\mathrm{Y})$ indicates the baseline (endline) sample size. The realized sample size is slightly smaller than the initial sample size due to girls that couldn't be reached at endline. See Section 2.2 of paper for details on the interventions, and Section 3.2 of paper for details on attrition.

views compared to in self-administered surveys) (we discuss the effect of the administration mode in Chuang et al., 2017). The comparison between columns 1 and 2 suggests that the year we focus on turns out to be an important year for teenage girls: about $17 \%$ of them initiate sexual activity during that time, and the share who has started chilbearing triples. The great majority of pregnancies are unplanned.

School-Based HIV Education The government of Cameroon authorized school-based HIV prevention programs in 2004 as HIV was recognized a national priority. As of 2009, HIV/AIDS prevention education had not been integrated into the standard curriculum for either primary or secondary school. Teacher training was part of the governmental strategy for HIV/AIDS prevention education but only $2.6 \%$ of schools had trained teachers by 2009 . While individual teachers or other school personnel (e.g. counsellors) could take the initiative to discuss about HIV with students, a 2010 survey administered to school staff by the Institute for Research, Socio-economic Development and Communication (IRESCO) suggests that while most of them had a relatively good knowledge and understanding of HIV, they did not know how to teach this material and felt they needed a special training. In particular, most school staff members were reluctant to talk about condoms, fearing that discussing condoms in the classroom would be akin to encouraging promiscuity, and those who did teach about HIV focused on abstinence education.

Discussions between the research team and the Ministry of Education suggested a high level of interest in understanding how best to introduce HIV prevention in secondary schools. One key question that arose was that of the "messenger" namely, who should be delivering HIV prevention information? Regular school teachers trained on this issue, or specialized health professionals that could rotate across schools? The experiment was designed in part to answer this question.

\subsection{Experimental design}

The study was conducted in partnership with IRESCO, a Cameroon-based non-profit organization special- izing in reproductive health and health education.

Fig. 2 summarizes the experimental design. The experiment involved 318 middle schools. These schools were first assigned, through block-randomization, to one of four training groups: (1) control, (2) teacher training on the regular HIV prevention curriculum, (3) a 60-min HIV session on the regular HIV prevention curriculum delivered by an outside consultant, and (4) a 60-min HIV session on the regular HIV prevention curriculum delivered by an outside consultant, including the "Sugar Daddy Risk Awareness" information from Dupas (2011). Allocation of the 318 schools into these four training 
arms was done within 4-school strata based on region, whether the school was a stand-alone junior high school or attached to a senior high school, the school's tertile in terms of performance on the junior high school leaving exam (BEPC), and the school's tertile in terms of student gender ratio.

We then randomly sampled $1 / 2$ of the schools for an In-Class Quiz on HIV risk and sexual behavior. Note that the random assignment of schools to the In-Class Quiz was done within each training arms, but not within strata since these strata contained only four schools. ${ }^{6}$

This cross-randomization generates a control group and 7 treatment categories, as presented in Fig. 1. We describe each component in detail below.

In-Class Quiz ( $\mathbf{Q} 159$ schools) Each school in this group was visited by IRESCO and students in the selected grade 8 class were given a quiz to fill in class. The quiz was anonymous, group-administered, and included 44 questions in total. The modules were: basic demographics (including childbearing history and current pregnancy status), HIV knowledge (beliefs about prevalence by age groups, beliefs about transmission modes, prevention methods), sexual behavior of peers (e.g. "How many girls in your class have a boyfriend?"), beliefs about the risks of pregnancy and HIV infections per unprotected sex act, and own sexual behavior. All students in the selected 8th-grade class were given a chance to fill out the quiz, during a session which took an hour on average to complete, including the introduction and informed consent process. Each question was read aloud by the IRESCO facilitator. ${ }^{7}$

Teacher Training (TT, 80 schools) Each school in this group was invited to send one permanent staff member to a two-day training held in the region capital city. The training was organized by IRESCO and was focused on HIV prevention education pedagogy, providing trainees with ways to talk about HIV and prevention of HIV with students, scripts and lesson materials, including a Q\&A manual. The training encouraged teachers to promote all modes of avoiding infection (abstinence, faithfulness and condom use). Compliance to treatment assignment was very high: $96 \%$ of schools (77 out of 80 ) sent one permanent staff member to the training, among which 53\% sent a teacher to these trainings (most often a biology teacher), around a quarter sent the after-school facilitator (the person in charge of extra-curricular activities after school and on Wednesday afternoons), and the remainder sent other non-teaching staffs (hall monitors, counselors, directors of studies). Schools did not receive any specific requirement about the gender of the trainees and it turned out that $70 \%$ of the trainees were men. This is to be noted in the comparison of the effects between the Teacher Training intervention and the Consultant interventions, as teenage girls may be more responsive to information received from women than from men. After the training, the trained facilitators were responsible for holding as many sessions as they wanted in their school, prioritizing the targeted 8th grade class.

Session with a Consultant (C, 79 schools) This treatment was implemented by female external pro- fessionals who were also trained by IRESCO. The training course and materials that was given to the consultants prior to the intervention had exactly the same content as the training course given to the school staff members. The external consultants came to the school just once to deliver the same basic message as in the TT intervention. The external consultant provided a single session, showed two short videos on abstinence and condom use and facilitated a discussion of these issues among students in the class. In total, the intervention lasted around one hour. In this treatment, the content of the information delivered should be the same as in the TT intervention but the format of the intervention is different in terms of duration, number of sessions, and relation of the messenger to students. While the consultant sessions may be more attractive thanks to the use of videos and the expertise of the messenger, the inconvenient of this delivery mode is that it provides only one session while teachers are encouraged to provide several sessions. Teachers can also treat virtually all classes while the consultants treat only one class. In case of positive inter-class spillovers, it gives an advantage to the teacher training treatment over the consultant treatment.

Session with a Consultant with Sugar Daddy risk message ( $C+, 79$ schools) This treatment mirrors the Consultant treatment but in addition to the information delivered in the previous treatment, the consultant provided detailed information on HIV infection rates by gender and age groups, highlighting the risks associated with "sugar daddy" relationships (called "sponsor" relationships in Cameroon) and their responsibility for the cross-generational transmission of HIV. In addition to the two videos on abstinence and condom use as in the Consultant intervention, the consultant also showed a longer video on risks associated

with "sponsors". In total, the intervention was planned to have the same duration as in the Consultant group so that both groups differ only in the content of the information but not in the format of the session. This treatment is a replication of the Relative Risk treatment tested with similarly-aged girls in Kenya in 2004-2005 (Dupas, 2011).

Two external consultants, staff of IRESCO, each covered half of the schools in C treatment group and half of the schools in the $\mathrm{C}+$ treatment group. The rationale for having them do both treatments was to avoid confounding the message difference with the personality difference. A shortcoming of this design is that there appears to have been some contamination of the C intervention with some C+ information, as we will discuss in Section 4.1.

\footnotetext{
${ }^{6}$ To randomize within training arms and strata, each stratum must have contained 8 schools.

7 Questions were read aloud by the IRESCO facilitator to ensure that everyone follows and understand the questions, in an effort to improve data quality. According to the interviewers who administered the in-class quiz, students were not particularly embarrassed by the questions and the fact that questions were read out loud was not particularly disturbing.
} 
All intervention materials (training manuals and videos) are available online at https://www.povertyactionlab.org/ evaluation/risk-information-and-adolescent-sexual-behavior-cameroon.

The three education interventions (training the teachers or sending an outside messenger to the schools) had the same total cost: EUR 218 per school for sending an outside messenger and EUR 208 per school for training the teachers, i.e. $\$ 300$ and $\$ 288$ respectively in 2016 USD.

\subsection{Sampling}

The study took place in three French speaking regions of Cameroon, Yaoundé, South and West. Yaoundé is purely urban whereas the South and West regions are mostly rural. In total, these three regions totalized 527 junior high schools (middle schools). We excluded from the sample all faith schools as well as schools with fewer than 10 girls in 8th grade (our target grade). This left 326 schools out of which we randomly sampled 318. Appendix A Table A1 provides summary statistics on the schools in our sample.

In each school, one class was randomly selected for the study. This class was specifically targeted by the enumerators (in the In-Class Quiz group), the trained school staff members (in the TT group), and the consultants (in the C and C+ groups). While In-Class Quiz and the C and C+ interventions were implemented only in the selected class in each school, the school staff members were asked to prioritize the selected class but without any restriction regarding the other classes.

In each class selected for the study, 10 girls were chosen at random to form the study sample (for schools with fewer than 10 girls, all girls were enrolled in the study). In terms of the sampling procedure for female students, upon the first visit by the research team to the school, 10 girls were randomly selected from among those listed on the register and present that day. All schools were visited for the first time between January 25 and April 29, 2010. What differed across schools was the purpose of the first visit. For schools sampled for the In-Class Quiz, the first visit was to administer the quiz. For schools in the control and TT groups, a pure sampling visit was conducted. Finally, for schools sampled for a consultant visit, the first visit was for the consultant intervention. Overall, the sample contains 3154 girls enrolled in 318 schools selected for the study.

\subsection{Timeline}

The school year in Cameroon goes from September to June. The In-Class Quiz was conducted between January 25 and February 26, 2010. The trainings in the TT group took place February 15-23, 2010. The consultant visits in the C and C+ groups took place in March/April 2010.

Our estimates of treatment effects are based on an endline survey conducted between January 25 and April 29, 2011, which we describe in the next section. The average gap between the intervention and the follow-up is 57 weeks for the In-Class Quiz, 54 weeks for the Teacher Training, and 49 weeks for both the Consultant and Consultant+ interventions. The shorter span between intervention and endline in the consultant arms relative to the In-Class Quiz and Teacher Training arms decreases the potential impact on pregnancy of the consultant interventions conditional on a given "impact per month."

\section{Data and empirical strategy}

\subsection{Outcomes of interest}

The main source of data is the endline survey. For the survey, we attempted to trace back all sampled girls. If still in school, sampled girls were surveyed one by one on the school premises. If absent from school, they were visited at home. If girls could not be found in person, a relative or a friend was surveyed on a sub-set of objective outcomes (pregnancy history, school enrolment) that are common knowledge in the community. All sections of the questionnaire were administered individually in a dedicated room face-to-face with a female enumerator, except the section on sexual behavior: for half of the respondents, this section was self- administered on paper, while for the remainder it was also administered face-to-face with the enumerator. ${ }^{8}$ The endline survey measured three types of outcomes considered in the analysis.

Process and Intermediate outcomes: Exposure to HIV education, HIV knowledge, Perceived HIV risks, and avoidance plans In order to measure the compliance of school staff and consultants with the treatment assignments, a set of verification outcomes was collected. This includes information on exposure to HIV education, and content of HIV education. For instance, we would expect girls in the control group to report lower number of HIV education sessions than girls in the treatment groups, or girls in the C+ group to remember message about relative risk of "sugar daddies" significantly more than girls in other treatment groups. Mostly open-ended questions were used. The endline survey also contained questions on HIV/AIDS-

\footnotetext{
${ }^{8}$ The random assignment of schools to the face-to-face or self-administered version of the survey was (mistakenly) not stratified by treatment status. The resulting assignment is somewhat unbalanced: schools in the Q QC and C+ groups are $12-16 \%$ points less likely to have been assigned to the selfadministration group, though the differences are not significant at conventional levels (see Appendix A Table A1, last column). The administration mode had some limited effects on reports for the most sensitive sexual behavior questions, though not on reported childbearing history. The results are entirely robust to including or excluding a control for the survey administration mode.
} 
related knowledge (modes of transmission and prevention), perceived risks (prevalence of HIV, probability to get infected in different situations), and avoidance plans for the next year.

Primary outcome: Pregnancy Self-reported sexual behavior can be unreliable due to the social de- sirability bias. We consider childbearing as a more objective measure and proxy for risky sexual conduct. Another advantage is that this outcome can be reported without a direct interview, since childbearing history is usually common knowledge in the community.

We also collected information on dropouts. As mentioned above, a history of pregnancy does not preclude girls from staying in school in this context, in contrast with the female students in Kenya studied in Duflo et al. (2015).

\subsection{Validation of the experimental design}

Balance Tests Appendix A Table A1 presents summary statistics of the schools in the sample, and balance tests in those characteristics across treatment arms. There is some imbalance in the type of schools (the Teacher Training group has more vocational schools) and the student/teacher ratio (it is higher among schools sampled for the Consultant Only (C) intervention). The other pre-treatment characteristics are balanced across treatment arms, so the means are significantly different in 2 out of the 56 tests. The balance checks thus do not reject the assumption that each treatment group is statistically identical to the control group. In the tables of results, we will show the results both including and excluding school-level controls. We find qualitatively similar estimates across specifications, suggesting that the bias introduced by the initial differences between groups does not account for the main results.

Implementation of the randomized assignment Regarding compliance with treatment assignment, a handful of schools did not receive the treatment they were assigned to: 3 schools out of 80 in the TT group had nobody from the school staff attending the training; one school in the control group was used to pre-test the C+ intervention, by error; finally, another school in the control group was visited by a staff member of a neighboring school belonging to the TT group to run an HIV education session. The compliance rate is thus very high, at $98.5 \%$, and we focus on the intention-to-treat estimator.

Attrition Out of 3154 girls in our sample, we obtained information (in-person interview or relative interview) for 2907 of them. This constitutes an overall $7.8 \%$ attrition rate (247 girls lost) for objective outcomes (pregnancy history and school enrolment). Part of this comes from the fact that endline data could not be collected at all from three schools (30 girls).

Among the 2907 girls for whom we obtained information, 2732 were interviewed in-person. Therefore the attrition rate for self-reported sexual behavior outcomes is $13.4 \%$ ( 422 girls lost). The high attrition rate is not entirely surprising as girls are at a highly unsteady age and are likely to move away. Furthermore, our rate remains within the range of attrition rates observed in comparable experimental settings. ${ }^{9}$

In Appendix A Table $\mathrm{A} 2$ we test whether the attrition rate is differential across treatment arms. One coefficient is significant at the 10\% level: girls sampled for the In-Class Quiz Only treatment were 5.2\% points less likely to be surveyed in person (column 4). In the main table of results (Table 4), we show the key outcome results (childbearing) both including and excluding those not surveyed in person. We find similar estimates, suggesting that the bias introduced by the heightened attrition in the in-person survey for the In-Class Quiz Only group does not account for the main results.

\subsection{Empirical strategy}

We are interested in measuring the impact of the three types of interventions, as well as of the In-Class Quiz itself. The impact of the In-Class Quiz and the education interventions can be estimated within a simple regression framework. The equation for each outcome is:

$$
Y_{i s}=\alpha+\beta Q_{s}+\boldsymbol{E}_{s}^{\prime} \gamma+\mathbf{Q E}_{s} \delta+\mathbf{X}_{i}^{\prime} \mu+\mathbf{Z}_{s}{ }_{s} \eta+\varepsilon_{i s},
$$

where $Y_{i s}$ is a dependent variable for individual $i$ attending school $s ; Q_{s}$ is a dummy variable for schools selected for the In-Class Quiz but not for the education interventions ( $Q$ only); $\mathbf{E}_{s s}$ is a vector of dummy variables designating participation of a school in a particular education intervention (TT, C or C + ) but not in the In-Class Quiz; $\mathbf{Q E}_{S}$ is a vector of dummy variables for schools selected for both the In-Class Quiz and one of the education interventions; $\mathbf{X}_{i}$ is a vector of individual-level controls collected at endline; $\mathbf{Z}_{s}$ is a vector of school-level controls including variables used for stratification; and $\varepsilon i s$ is the error term. The standard errors are clustered at the school level.

In Eq. (1), $\beta$ represents the effect of the In-Class Quiz alone; $\gamma$ represents the effect of the education interventions alone; and $\delta$ represents the joint effects. We also present additional specifications in Appendix A Table A5. The first specification (Panel A) presents the joint impact of all interventions (in-class quiz and any educational interventions: Q, TT; QTT, C, QC, C+ $\mathrm{QC}+$ ) by comparing the control group with all treatment groups pooled together. The second specification (Panel B) provides evidence on the impacts of the in-class quiz (Q), any educational interventions without the in-class quiz (TT, C, C+), and the combination of the in-class quiz and any educational interventions (QTT, QC, and QC+). This specification compares the effect of the in-class quiz and the educational interventions together, and tests the complementarity/substitutability between educational interventions and the quiz. The third specification (Panel $C)$ pools all interventions together $(Q, T T$,

\footnotetext{
${ }^{9}$ For example, Godlonton et al. (2016) have a 30\% attrition rate among men in Malawi over a 12-month follow-up period.
} 
QTT, C, QC, C+, QC+) and tests the added-value of the consultant delivery mode (C, QC, C+, QC+) and the added-value of the sugar daddy message $(\mathrm{C}+, \mathrm{QC}+)$. This specification tests whether the consultant delivery method is more or less effective than the teacher delivery method, as well as the added-value of the sugar daddy information.

For each outcome, the ordinary least squares (OLS) estimator is reported. For each dependent variable, we also report the mean of the control group, and p-values for the tests that the effects of different types of treatments are the same, that treatment effects are jointly zero, and that treatment effects are all equal. We show three specifications: basic controls, basic + school-level controls, basic + school + individual-level controls. The set of basic controls include: region dummies, whether the endline survey was conducted in- person or with a relative, whether it was randomized to being selfadministered or face-to-face, and the week during which the endline survey was conducted (since the endline period spanned a period of 3 months).

The school-level controls include the characteristics shown in Appendix A Table A1. The individual level controls include age, age squared, and dummies for the education level of the female guardian. ${ }^{10,11}$ As a robustness check, Appendix A Table A4 presents the probit estimators for our main outcome: pregnancy. Given the number of outcomes considered, a possible concern with our analysis is overrejection of the null hypothesis due to multiple inference. To deal with this, we compute False Discovery Rate sharpened q-values (Benjamini et al., 2006) using the procedure in Anderson (2008). To construct q-values, we include the p-values of all outcomes for which we had strong theoretical reasons to expect impacts (Total Time (minutes) of HIV education in past 12 months, Had HIV education led by external consultants, Has started childbearing, Currently pregnant, Dropped out, Personal plan to avoid HIV infection in coming year: Number of strategies listed, Plans to abstain, Plans to use condoms, Knowledge Index, and Perceived Risk Index - in total, 10 outcomes). Q-values are presented in Appendix A Table A6.

\section{Results}

\subsection{HIV education exposure}

Table 2 presents the results on process outcomes: whether the interventions affected reported exposure to HIV information sessions. Looking first at the Mean for the control group (row 9), the level of HIV education that goes on absent any intervention is non-negligible. Column 1 shows that $28 \%$ of students in the control group report having attended at least one formal HIV education session in the previous 12 months where the average total time in HIV education sessions over the year is $40 \mathrm{~min}$. These HIV education sessions are held both by school staff and outside consultants, and appear to be comprehensive in their context, covering the "ABCs" (abstinence, be faithful, condoms) as well as HIV transmission information, and in some cases "sponsors".

The first row in Table 2 shows how the In-Class Quiz, by itself, was a memorable event for the stu- dents. This is particularly interesting because it tells us whether it was perceived by the students as an "intervention". While most of the coefficients on the outcomes in Table 2 are individually not significant at conventional levels, their magnitude is not trivial. In particular, compared to the control group, students exposed to the Quiz are $10 \%$ points more likely to report having had an HIV education session in the past 12 months (a 35\% increase, p-val =0.12), and 12\% points (a 67\% increase, significant at 5\% level) more likely to report having had a session by an external consultant.

The other coefficient estimates in Table 2 show that, reassuringly, both the teacher training and the consultant interventions increased reported exposure to HIV education by a lot. The consultant interventions (be it C or C+) were more memorable than those led by teachers (an extra 36-39\% points of students remember the consultants-led sessions, vs. only $22 \%$ points for the TT interventions). The treatments covered the ABCs, but as designed, the $\mathrm{C}+$ treatment had a special focus on "sponsors". This special focus did permeate the C interventions however, possibly owing to the fact that the same two women were in charge of implementing the consultant interventions, who had difficulty holding back on the "sponsors" message in the schools sampled for the $C$ intervention. As a result, the $C$ intervention had a significant impact on exposure to the sponsors message, though not as high as the $\mathrm{C}+$ intervention.

\subsection{Knowledge, perceived risks, and personal HIV prevention plan}

Table 3 presents the results on knowledge. The first outcome we consider is misperception with regards to whether mosquitoes transmit HIV. Looking at this outcome is interesting because it sheds light on how the In-Class Quiz affected students. The coeffcient for the Quiz alone is negative and significant, suggesting that the Quiz had the perverse effect of making students even more confused about this issue: the likelihood that they are correct dropped by $7 \%$ points, a $16 \%$

\footnotetext{
10 We do not include dummies for the strata used for the first randomization because these strata contain only four schools while there are eight treatment types. Thus one stratum does not contain one school of each treatment type.

11 We do not include more individual-level controls since individual level characteristics were measured at endline and could have been affected by the treatments. Age and maternal education are obvious time invariant characteristics that are safe to include.
} 
Table 2

Impacts on HIV education exposure.

\begin{tabular}{|c|c|c|c|c|c|c|c|c|c|c|c|c|c|}
\hline & $\begin{array}{l}(1) \\
\text { Had HIV } \\
\text { education at } \\
\text { school in past } \\
12 \text { months }\end{array}$ & $\begin{array}{l}\text { (2) } \\
\text { Number of } \\
\text { HIV } \\
\text { teducation } \\
\text { sessions }\end{array}$ & $\begin{array}{l}\text { (3) } \\
\text { Total Time } \\
\text { (minutes) of } \\
\text { HIV } \\
\text { education in } \\
\text { past } 12 \\
\text { months }\end{array}$ & $\begin{array}{l}(4) \\
\text { Had HIV } \\
\text { education led } \\
\text { by external } \\
\text { consultants }\end{array}$ & $\begin{array}{l}(5) \\
\text { Had HIV } \\
\text { d education led } \\
\text { by school } \\
\text { staff }\end{array}$ & $\begin{array}{l}(6) \\
\text { Themes } \\
\text { d covered } \\
\text { included } \\
\text { condoms }\end{array}$ & $\begin{array}{l}\text { (7) } \\
\text { Themes } \\
\text { covered } \\
\text { included } \\
\text { abstinence }\end{array}$ & $\begin{array}{l}\text { (8) } \\
\text { Themes } \\
\text { covered } \\
\text { included } \\
\text { faithfulness }\end{array}$ & $\begin{array}{l}\text { (9) } \\
\text { Themes } \\
\text { covered } \\
\text { included } \\
\text { "sponsors" }\end{array}$ & $\begin{array}{l}(10) \\
\text { Themes } \\
\text { covered } \\
\text { included HIV } \\
\text { transmission }\end{array}$ & $\begin{array}{l}\text { (11) } \\
\text { Movies were } \\
\text { shown } \\
\text { during } \\
\text { session }\end{array}$ & $\begin{array}{l}(12) \\
\text { Could ask } \\
\text { questions } \\
\text { during } \\
\text { session }\end{array}$ & $\begin{array}{l}(13) \\
\text { Asked } \\
\text { question } \\
\text { during } \\
\text { session }\end{array}$ \\
\hline In-Class Quiz Only (Q) & $\begin{array}{l}0.10 \\
(0.064)\end{array}$ & $\begin{array}{l}0.19 \\
(0.180)\end{array}$ & $\begin{array}{l}5.78 \\
(12.289)\end{array}$ & $\begin{array}{l}0.12^{* *} \\
(0.058)\end{array}$ & $\begin{array}{l}0.03 \\
(0.053)\end{array}$ & $\begin{array}{l}0.09 \\
(0.061)\end{array}$ & $\begin{array}{l}0.09 \\
(0.062)\end{array}$ & $\begin{array}{l}0.10 \\
(0.062)\end{array}$ & $\begin{array}{l}0.02 \\
(0.040)\end{array}$ & $\begin{array}{l}0.07 \\
(0.059)\end{array}$ & $\begin{array}{l}-0.04 \\
(0.036)\end{array}$ & $\begin{array}{l}0.10 \\
(0.063)\end{array}$ & $\begin{array}{l}0.03 \\
(0.033)\end{array}$ \\
\hline Teacher Training Only (TT) & $\begin{array}{l}0.22^{* * * *} \\
(0.062)\end{array}$ & $\begin{array}{l}1.29^{* * *} \\
(0.419)\end{array}$ & $\begin{array}{l}64.32^{* * *} \\
(16.213)\end{array}$ & $\begin{array}{l}0.03 \\
(0.057)\end{array}$ & $\begin{array}{l}0.24^{* * *} \\
(0.063)\end{array}$ & $\begin{array}{l}0.19 * * * \\
(0.059)\end{array}$ & $\begin{array}{l}0.23^{* * *} \\
(0.061)\end{array}$ & $\begin{array}{l}0.23^{* * *} \\
(0.062)\end{array}$ & $\begin{array}{l}0.07^{*} \\
(0.042)\end{array}$ & $\begin{array}{l}0.21^{* * *} \\
(0.059)\end{array}$ & $\begin{array}{l}-0.01 \\
(0.040)\end{array}$ & $\begin{array}{l}0.23^{* * *} \\
(0.062)\end{array}$ & $\begin{array}{l}0.19^{* * *} \\
(0.040)\end{array}$ \\
\hline $\begin{array}{l}\text { In-Class Quiz + Teacher } \\
\text { Training (QTT) }\end{array}$ & $\begin{array}{l}0.23^{* * * *} \\
(0.066)\end{array}$ & $\begin{array}{l}0.78^{* * *} \\
(0.247)\end{array}$ & $\begin{array}{l}60.51^{* * *} \\
(15.662)\end{array}$ & $\begin{array}{l}0.09 \\
(0.060)\end{array}$ & $\begin{array}{l}0.23^{* * *} \\
(0.065)\end{array}$ & $\begin{array}{l}0.21^{\text {**** }} \\
(0.063)\end{array}$ & $\begin{array}{l}0.23^{* * *} \\
(0.065)\end{array}$ & $\begin{array}{l}0.24^{* * *} \\
(0.065)\end{array}$ & $\begin{array}{l}0.01 \\
(0.040)\end{array}$ & $\begin{array}{l}0.20^{* * *} \\
(0.063)\end{array}$ & $\begin{array}{l}-0.04 \\
(0.038)\end{array}$ & $\begin{array}{l}0.23^{* * *} \\
(0.066)\end{array}$ & $\begin{array}{l}0.16^{* * *} \\
(0.041)\end{array}$ \\
\hline Consultant Only (C) & $\begin{array}{l}0.39^{* * *} \\
(0.062)\end{array}$ & $\begin{array}{l}0.49^{* * *} \\
(0.145)\end{array}$ & $\begin{array}{l}55.13^{* * *} \\
(13.997)\end{array}$ & $\begin{array}{l}0.44^{* * *} \\
(0.060)\end{array}$ & $\begin{array}{l}0.05 \\
(0.051)\end{array}$ & $\begin{array}{l}0.38^{* * *} \\
(0.061)\end{array}$ & $\begin{array}{l}0.39^{* * *} \\
(0.060)\end{array}$ & $\begin{array}{l}0.38^{* * *} \\
(0.060)\end{array}$ & $\begin{array}{l}0.13^{* * *} \\
(0.043)\end{array}$ & $\begin{array}{l}0.37^{* * *} \\
(0.061)\end{array}$ & $\begin{array}{l}0.42^{* * *} \\
(0.059)\end{array}$ & $\begin{array}{l}0.38^{* * *} \\
(0.062)\end{array}$ & $\begin{array}{l}0.22^{* * *} \\
(0.042)\end{array}$ \\
\hline $\begin{array}{l}\text { In-Class Quiz + Consultant } \\
\text { (QC) }\end{array}$ & $\begin{array}{l}0.36^{* * * *} \\
(0.057)\end{array}$ & $\begin{array}{l}0.61^{* * *} \\
(0.139)\end{array}$ & $\begin{array}{l}53.49^{* * *} \\
(12.760)\end{array}$ & $\begin{array}{l}0.42^{* * *} \\
(0.057)\end{array}$ & $\begin{array}{l}0.10^{*} \\
(0.055)\end{array}$ & $\begin{array}{l}0.34^{* * *} \\
(0.056)\end{array}$ & $\begin{array}{l}0.35^{* * *} \\
(0.056)\end{array}$ & $\begin{array}{l}0.34^{* * *} \\
(0.058)\end{array}$ & $\begin{array}{l}0.14^{* * *} \\
(0.045)\end{array}$ & $\begin{array}{l}0.29^{* * *} \\
(0.056)\end{array}$ & $\begin{array}{l}0.46^{* * *} \\
(0.051)\end{array}$ & $\begin{array}{l}0.35^{* * *} \\
(0.059)\end{array}$ & $\begin{array}{l}0.19^{* * *} \\
(0.038)\end{array}$ \\
\hline Consultant Plus Only $(\mathrm{C}+)$ & $\begin{array}{l}0.39^{* * *} \\
(0.062)\end{array}$ & $\begin{array}{l}0.51^{* * *} \\
(0.149)\end{array}$ & $\begin{array}{l}51.79^{* * *} \\
(13.071)\end{array}$ & $\begin{array}{l}0.46^{* * * *} \\
(0.062)\end{array}$ & $\begin{array}{l}0.01 \\
(0.052)\end{array}$ & $\begin{array}{l}0.36^{* * *} \\
(0.060)\end{array}$ & $\begin{array}{l}0.39^{* * *} \\
(0.060)\end{array}$ & $\begin{array}{l}0.38^{* * * *} \\
(0.062)\end{array}$ & $\begin{array}{l}0.43^{* * *} \\
(0.055)\end{array}$ & $\begin{array}{l}0.35^{* * *} \\
(0.062)\end{array}$ & $\begin{array}{l}0.57^{* * *} \\
(0.056)\end{array}$ & $\begin{array}{l}0.39^{* * *} \\
(0.063)\end{array}$ & $\begin{array}{l}0.23^{* * *} \\
(0.042)\end{array}$ \\
\hline $\begin{array}{l}\text { In-Class Quiz + Consultant } \\
\text { Plus (QC+) }\end{array}$ & $0.38^{* * *}$ & $0.65^{* * *}$ & $79.42^{* * *}$ & $0.43^{* * *}$ & 0.09 & $0.37^{* * *}$ & $0.39^{* * *}$ & $0.39^{* * *}$ & $0.35^{* * *}$ & $0.35^{* * *}$ & $0.43^{* * *}$ & $0.38^{* * *}$ & $0.18^{* * *}$ \\
\hline & $(0.061)$ & $(0.135)$ & $(14.365)$ & $(0.063)$ & $(0.060)$ & $(0.058)$ & $(0.060)$ & $(0.061)$ & $(0.052)$ & $(0.058)$ & $(0.058)$ & $(0.063)$ & $(0.042)$ \\
\hline Number of Observations & 2732 & 2676 & 2618 & 2732 & 2732 & 2732 & 2732 & 2732 & 2732 & 2732 & 2726 & 2731 & 2732 \\
\hline Mean of Dep. Var. (Control) & 0.282 & 0.438 & 40.142 & 0.184 & 0.175 & 0.264 & 0.264 & 0.261 & 0.138 & 0.250 & 0.086 & 0.261 & 0.098 \\
\hline R-squared & 0.166 & 0.100 & 0.111 & 0.203 & 0.093 & 0.152 & 0.159 & 0.158 & 0.134 & 0.138 & 0.325 & 0.157 & 0.081 \\
\hline$P$-value for the test $Q=T T$ & 0.058 & 0.013 & 0.000 & 0.121 & 0.001 & 0.092 & 0.029 & 0.035 & 0.158 & 0.016 & 0.262 & 0.031 & 0.000 \\
\hline $\mathrm{P}$-value for the test $\mathrm{Q}=\mathrm{C}$ & 0.000 & 0.099 & 0.001 & 0.000 & 0.623 & 0.000 & 0.000 & 0.000 & 0.010 & 0.000 & 0.000 & 0.000 & 0.000 \\
\hline P-value for the test $\mathrm{Q}=\mathrm{C}+$ & 0.000 & 0.081 & 0.001 & 0.000 & 0.764 & 0.000 & 0.000 & 0.000 & 0.000 & 0.000 & 0.000 & 0.000 & 0.000 \\
\hline $\begin{array}{l}\text { P-value for the test } \\
\text { TT = QTT }\end{array}$ & 0.894 & 0.316 & 0.845 & 0.239 & 0.951 & 0.773 & 0.983 & 0.904 & 0.151 & 0.938 & 0.367 & 0.991 & 0.476 \\
\hline$P$-value for the test $C=Q C$ & 0.573 & 0.399 & 0.913 & 0.788 & 0.433 & 0.449 & 0.428 & 0.468 & 0.831 & 0.189 & 0.523 & 0.547 & 0.601 \\
\hline $\begin{array}{l}\text { P-value for the test } \\
\qquad+=Q C+\end{array}$ & 0.918 & 0.375 & 0.085 & 0.730 & 0.199 & 0.966 & 0.928 & 0.863 & 0.258 & 0.943 & 0.061 & 0.831 & 0.406 \\
\hline $\begin{array}{l}\text { P-value for the test that } \\
\text { treatments are all equal }\end{array}$ & 0.000 & 0.034 & 0.000 & 0.000 & 0.000 & 0.000 & 0.000 & 0.000 & 0.000 & 0.000 & 0.000 & 0.000 & 0.000 \\
\hline
\end{tabular}

Notes: Data from endline survey. Sample restricted to girls who were administered endline survey in person. Estimates from an OLS regression. Standard errors clustered at school level * Significance at $10 \%$

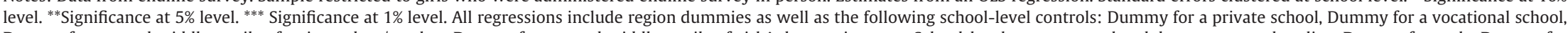

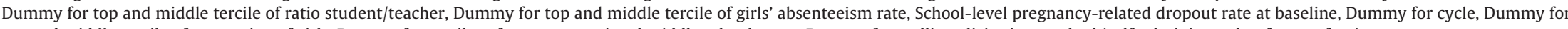
top and middle tercile of proportion of girls, Dummy for terciles of scores on national middle school exam, Dummy for endline elicitation method (self-administered or face-to-face). 
Table 3

Impacts on HIV knowledge

\begin{tabular}{|c|c|c|c|c|c|c|c|c|}
\hline & $\begin{array}{l}(1) \\
\text { Knows } \\
\text { mosquitoes do } \\
\text { not transmit HIV }\end{array}$ & $\begin{array}{l}\text { (2) } \\
\text { Knows that girls } \\
\text { aged } 15-19 \text { have } \\
\text { a higher HIV } \\
\text { infection rate } \\
\text { than boys in that } \\
\text { age range }\end{array}$ & $\begin{array}{l}\text { (3) } \\
\text { Knows older men } \\
\text { are riskier } \\
\text { partners in terms } \\
\text { of HIV }\end{array}$ & $\begin{array}{l}(4) \\
\text { Thinks condoms } \\
\text { are very effective }\end{array}$ & $\begin{array}{l}\text { (5) } \\
\text { Mentions } \\
\text { condoms as a } \\
\text { way to avoid HIV }\end{array}$ & $\begin{array}{l}\text { (6) } \\
\text { Mentions fidelity } \\
\text { as a way to avoid } \\
\text { HIV }\end{array}$ & $\begin{array}{l}\text { (7) } \\
\text { Mentions } \\
\text { abstinence as a } \\
\text { way to avoid HIV }\end{array}$ & $\begin{array}{l}\text { (8) } \\
\text { Knowledge } \\
\text { Index }^{\mathrm{a}}\end{array}$ \\
\hline In-Class Quiz Only (Q) & $\begin{array}{l}-0.073^{*} \\
(0.040)\end{array}$ & $\begin{array}{l}0.054 \\
(0.040)\end{array}$ & $\begin{array}{l}0.035 \\
(0.049)\end{array}$ & $\begin{array}{l}0.038 \\
(0.042)\end{array}$ & $\begin{array}{l}-0.034 \\
(0.030)\end{array}$ & $\begin{array}{l}0.011 \\
(0.052)\end{array}$ & $\begin{array}{l}0.000 \\
(0.053)\end{array}$ & $\begin{array}{l}0.005 \\
(0.040)\end{array}$ \\
\hline Teacher Training Only (TT) & $\begin{array}{l}0.044 \\
(0.043)\end{array}$ & $\begin{array}{l}0.076^{* *} \\
(0.038)\end{array}$ & $\begin{array}{l}0.038 \\
(0.047)\end{array}$ & $\begin{array}{l}0.089^{* *} \\
(0.045)\end{array}$ & $\begin{array}{l}-0.023 \\
(0.034)\end{array}$ & $\begin{array}{l}0.078 \\
(0.053)\end{array}$ & $\begin{array}{l}0.062 \\
(0.055)\end{array}$ & $\begin{array}{l}0.105^{* * *} \\
(0.040)\end{array}$ \\
\hline In-Class Quiz + Teacher Training (QTT) & $\begin{array}{l}0.028 \\
(0.043)\end{array}$ & $\begin{array}{l}0.075^{*} \\
(0.044)\end{array}$ & $\begin{array}{l}0.067 \\
(0.050)\end{array}$ & $\begin{array}{l}0.120^{* * *} \\
(0.047)\end{array}$ & $\begin{array}{l}-0.001 \\
(0.029)\end{array}$ & $\begin{array}{l}0.074 \\
(0.051)\end{array}$ & $\begin{array}{l}0.114^{* *} \\
(0.053)\end{array}$ & $\begin{array}{l}0.139 * * * \\
(0.044)\end{array}$ \\
\hline Consultant Only (C) & $\begin{array}{l}0.056 \\
(0.041)\end{array}$ & $\begin{array}{l}0.035 \\
(0.043)\end{array}$ & $\begin{array}{l}0.041 \\
(0.046)\end{array}$ & $\begin{array}{l}0.078^{*} \\
(0.045)\end{array}$ & $\begin{array}{l}-0.086^{* *} \\
(0.033)\end{array}$ & $\begin{array}{l}-0.004 \\
(0.046)\end{array}$ & $\begin{array}{l}0.078 \\
(0.053)\end{array}$ & $\begin{array}{l}0.051 \\
(0.036)\end{array}$ \\
\hline In-Class Quiz + Consultant (QC) & $\begin{array}{l}0.226^{* * *} \\
(0.042)\end{array}$ & $\begin{array}{l}0.059 \\
(0.042)\end{array}$ & $\begin{array}{l}0.007 \\
(0.049)\end{array}$ & $\begin{array}{l}0.069 \\
(0.043)\end{array}$ & $\begin{array}{l}-0.032 \\
(0.031)\end{array}$ & $\begin{array}{l}0.013 \\
(0.053)\end{array}$ & $\begin{array}{l}0.008 \\
(0.057)\end{array}$ & $\begin{array}{l}0.104^{* *} \\
(0.044)\end{array}$ \\
\hline Consultant Plus Only (C+) & $\begin{array}{l}0.080^{* * *} \\
(0.038)\end{array}$ & $\begin{array}{l}0.065^{*} \\
(0.038)\end{array}$ & $\begin{array}{l}0.097^{*} \\
(0.049)\end{array}$ & $\begin{array}{l}0.122^{* *} \\
(0.048)\end{array}$ & $\begin{array}{l}0.002 \\
(0.030)\end{array}$ & $\begin{array}{l}0.054 \\
(0.048)\end{array}$ & $\begin{array}{l}0.051 \\
(0.051)\end{array}$ & $\begin{array}{l}0.139 * * * \\
(0.035)\end{array}$ \\
\hline In-Class Quiz + Consultant Plus (QC+) & $\begin{array}{l}0.155^{* * * *} \\
(0.047)\end{array}$ & $\begin{array}{l}0.079^{* *} \\
(0.039)\end{array}$ & $\begin{array}{l}0.101^{* *} \\
(0.045)\end{array}$ & $\begin{array}{l}0.110^{* * * *} \\
(0.040)\end{array}$ & $\begin{array}{l}-0.009 \\
(0.033)\end{array}$ & $\begin{array}{l}0.068 \\
(0.047)\end{array}$ & $\begin{array}{l}0.057 \\
(0.055)\end{array}$ & $\begin{array}{l}0.163^{* * * *} \\
(0.042)\end{array}$ \\
\hline Number of Observations & 2731 & 2729 & 2731 & 2670 & 2670 & 2670 & 2670 & 2665 \\
\hline Mean of Dep. Var. (Control) & 0.440 & 0.624 & 0.391 & 0.289 & 0.831 & 0.399 & 0.510 & 0.002 \\
\hline R-squared & 0.064 & 0.075 & 0.024 & 0.019 & 0.024 & 0.017 & 0.043 & 0.074 \\
\hline$P$-value for the test $Q=T T$ & 0.008 & 0.568 & 0.944 & 0.240 & 0.764 & 0.200 & 0.232 & 0.021 \\
\hline$P$-value for the test $Q=C$ & 0.003 & 0.669 & 0.907 & 0.391 & 0.128 & 0.748 & 0.127 & 0.255 \\
\hline P-value for the test $\mathrm{Q}=\mathrm{C}+$ & 0.000 & 0.784 & 0.235 & 0.082 & 0.245 & 0.374 & 0.304 & 0.001 \\
\hline P-value for the test $T T=Q T T$ & 0.748 & 0.968 & 0.553 & 0.539 & 0.504 & 0.936 & 0.304 & 0.464 \\
\hline $\mathrm{P}$-value for the test $\mathrm{C}=\mathrm{QC}$ & 0.000 & 0.615 & 0.490 & 0.858 & 0.118 & 0.725 & 0.203 & 0.228 \\
\hline P-value for the test $\mathrm{C}+=\mathrm{QC}+$ & 0.130 & 0.731 & 0.933 & 0.807 & 0.732 & 0.769 & 0.906 & 0.568 \\
\hline P-value for the test that treatments are all equal & 0.000 & 0.959 & 0.401 & 0.505 & 0.180 & 0.400 & 0.321 & 0.003 \\
\hline
\end{tabular}

Notes: Data from endline survey. Sample restricted to girls who were administered endline survey in person. Estimates from an OLS regression. Standard errors clustered at school level. * Significance at $10 \%$

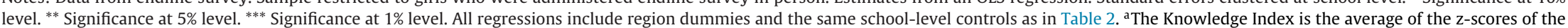
variables in columns (1) to (7). Each $z$-score is standardized mean $=0$, std. $\operatorname{dev}=1$, for the control group. 
decrease, significant at the $10 \%$ level. ${ }^{12}$ But those exposed to the Consultants and Teacher Training were much more likely to be correct than others. This suggests that the Quiz triggered a change in belief - seeing the question about mosquitoes as vectors in the Quiz made them think that it must be true. But once they had the opportunity to meet "an expert" (the outside health professional who came to their school a few weeks after the Quiz to talk about HIV), they were able to ask the question directly to the expert and learned the truth.

Table 3 also shows how the interventions affected beliefs about the age-gradient in HIV risk and condom effectiveness. Both teacher and consultant interventions increased awareness that teenage girls have a higher HIV infection rate than teenage boys. The Consultant+ intervention (both alone and combined with the Quiz) was also successful at increasing the understanding of the relationship between HIV-risk and age. The Teacher Training, Consultant and Consultant+ interventions all increased the perceived effectiveness of condoms. Although the point estimates are not precisely estimated, it seems that the Teacher Training and Consultant+ interventions increased the salience of fidelity and abstinence as ways to avoid HIV. They however did not increase the salience of condoms as a way to avoid HIV, which may be related to the fact that condoms are already the most common method mentioned (in the control group, $83 \%$ mention condoms, while only $40 \%$ mention fidelity and 51\% abstinence). Column 7 shows the effects on a Knowledge Summary Index, which is the average of the zscores of the variables in columns 1-6. The In-class Quiz did not affect general HIV knowledge, whereas all other interventions improved HIV knowledge by 0.05-0.16 standard deviation. This result is even more visible in Appendix A Table A5 Panel B Column 9: we see no impact of the In-class Quiz alone on the Knowledge Index, while a 0.099 standard deviation increase on average in the stand-alone educational intervention arms, and a 0.135 standard deviation increase on average in the combined In-class Quiz + educational intervention arms.

Perceived risks are measured by asking girls about probabilities to get HIV infected. These probabilities that are not common knowledge and not discussed in the educational interventions. Therefore, girls are generally wrong in assessing these probabilities. However, whether the interventions got these probabilities up or down relative to the control group allows us to capture the impacts of the interventions on perceived risks, which are presented in Appendix A Table A3. We first consider perceived prevalence of HIV in Cameroon. In the control group, the perceived prevalence is already widely exaggerated, at $47 \%$ (while actual prevalence was $4.3 \%$ in 2011). Perceived prevalence is higher in all treatment groups but none of the differences are significant except in the Quiz + Consultant intervention ( $+6.55 \%$ points). Columns $2-5$ of Appendix A Table A3 show the perceived probabilities to get HIV infected in different situations: unprotected intercourse, unprotected intercourses with different partners, a kiss, and protected intercourse with a partner at least 10-year older. In the control groups, these probabilities are respectively $61 \%, 90 \%, 11 \%$, and $23 \%$, pointing to the fact that girls are largely overanxious about the consequences of unsafe (and even safe) sex. However, the In-Class Quiz increased even further these probabilities by $1-6 \%$ points. Although most of these differences are not significant in isolation, the Perceived Risk Summary Index (averaging the z-scores of the variables in columns 1-5) in the Quiz group is 0.118 standard deviations above the mean in the control group, significant at the $1 \%$ level (column 6). As synthesized in Appendix A Table A5, Panel B, Column 10, the In-class Quiz thus increased perceived risks, whereas the education interventions and the combination of In-Class Quiz and educational interventions did not affect perceived risks.

Table 4 focuses on what girls report as their personal plan to avoid HIV infection. The specific question they were asked in the endline survey was: "People can do various things to protect themselves from HIV and other sexually transmitted infections. This year, do you plan to protect yourself one way or another?" (yes/no), and then it asked open-endedly: "In which way(s)?" Column 1 of Table 4 shows the number of strategies that students reported. Interestingly, all interventions reduced the number of strategies mentioned: the average is just over 2 in the control group, but it goes down significantly by around 0.3 in the intervention groups. The most common strategies mentioned in the control group are condoms (69\%) and abstinence (53\%). In the treatment groups, students were much more likely to pick one or the other - but not both. As a result, the share of students who mention condoms as a strategy is significantly lower in the intervention arms. The same goes for the other strategies, except for abstinence, which means that the interventions increased the likelihood that students report abstinence as their one, sole strategy. This is confirmed in Column 6 of Table 4, which shows the proportion of girls whose only plan is abstinence: while this proportion is $15 \%$ in the control group, it increases by $6-10 \%$ points in all treatment groups (most differences being significant). As shown in Appendix A Table A5, Column 7, the effect on planning to abstain is quite similar for all types of interventions, except less pronounced in groups which had the sugar daddy information (PanelC). We cannot ascertain whether this effect is "real" (a true change in plans), or whether the interventions changed what the respondents thought was the expected answer to the HIV prevention plan question. Since the interventions did not have an abstinence focus, there is no reason to think that this result is driven by social desirability bias - if social desirability bias made respondents more likely to report planning abstinence, they would be more likely to report planning using condoms as well, which is not the case (in fact the opposite). 
Table 4

Impacts on Personal HIV avoidance plan.

\begin{tabular}{|c|c|c|c|c|c|c|c|}
\hline & (1) & (2) & (3) & (4) & (5) & $(6)$ & (7) \\
\hline & $\begin{array}{l}\text { Personal plan to avoid HIV } \\
\text { infection in coming year: } \\
\text { Number of strategies listed }\end{array}$ & Plans to abstain & $\begin{array}{l}\text { Plans to limit } \\
\text { number of } \\
\text { partners }\end{array}$ & $\begin{array}{l}\text { Plans to change } \\
\text { how partners } \\
\text { will be chosen }\end{array}$ & Plans to use condoms & Plans to abstain only & Plans to use condoms only \\
\hline In-Class Quiz Only (Q) & $-0.350^{* *}$ & 0.051 & -0.066 & $-0.020^{* *}$ & $-0.132^{* * *}$ & $0.082^{* *}$ & -0.023 \\
\hline Teacher Training Only (TT) & $\begin{array}{l}-0.234 \\
(0.178)\end{array}$ & $\begin{array}{l}0.050 \\
(0.047)\end{array}$ & $\begin{array}{l}-0.065 \\
(0.065)\end{array}$ & $\begin{array}{l}-0.016^{*} \\
(0.009)\end{array}$ & $\begin{array}{l}-0.128^{* *} \\
(0.059)\end{array}$ & $\begin{array}{l}0.080^{*} \\
(0.045)\end{array}$ & $\begin{array}{l}-0.068^{* *} \\
(0.031)\end{array}$ \\
\hline In-Class Quiz + Teacher Training (QTT) & $\begin{array}{l}-0.174 \\
(0.168)\end{array}$ & $\begin{array}{l}0.097^{* *} \\
(0.045)\end{array}$ & $\begin{array}{l}-0.019 \\
(0.063)\end{array}$ & $\begin{array}{l}-0.015 \\
(0.010)\end{array}$ & $\begin{array}{l}-0.105^{* *} \\
(0.051)\end{array}$ & $\begin{array}{l}0.084^{* *} \\
(0.042)\end{array}$ & $\begin{array}{l}-0.057 \\
(0.037)\end{array}$ \\
\hline Consultant Only (C) & $\begin{array}{l}-0.319^{* * *} \\
(0.141)\end{array}$ & $\begin{array}{l}0.118^{* * * *} \\
(0.044)\end{array}$ & $\begin{array}{l}-0.092^{*} \\
(0.054)\end{array}$ & $\begin{array}{l}-0.016^{*} \\
(0.010)\end{array}$ & $\begin{array}{l}-0.127^{* * *} \\
(0.048)\end{array}$ & $\begin{array}{l}0.099^{* *} \\
(0.040)\end{array}$ & $\begin{array}{l}-0.028 \\
(0.032)\end{array}$ \\
\hline In-Class Quiz + Consultant (QC) & $\begin{array}{l}-0.302^{*} \\
(0.160)\end{array}$ & $\begin{array}{l}0.076^{*} \\
(0.046)\end{array}$ & $\begin{array}{l}-0.061 \\
(0.057)\end{array}$ & $\begin{array}{l}-0.013 \\
(0.012)\end{array}$ & $\begin{array}{l}-0.120^{* *} \\
(0.049)\end{array}$ & $\begin{array}{l}0.086^{* *} \\
(0.037)\end{array}$ & $\begin{array}{l}-0.054^{*} \\
(0.032)\end{array}$ \\
\hline Consultant Plus Only (C+) & $\begin{array}{l}-0.314^{* *} \\
(0.149)\end{array}$ & $\begin{array}{l}0.044 \\
(0.045)\end{array}$ & $\begin{array}{l}-0.085 \\
(0.057)\end{array}$ & $\begin{array}{l}-0.004 \\
(0.011)\end{array}$ & $\begin{array}{l}-0.089^{*} \\
(0.046)\end{array}$ & $\begin{array}{l}0.052 \\
(0.034)\end{array}$ & $\begin{array}{l}-0.011 \\
(0.035)\end{array}$ \\
\hline In-Class Quiz + Consultant Plus (QC+) & $\begin{array}{l}-0.329^{* *} \\
(0.148)\end{array}$ & $\begin{array}{l}0.024 \\
(0.046)\end{array}$ & $\begin{array}{l}-0.060 \\
(0.053)\end{array}$ & $\begin{array}{l}-0.018^{*} \\
(0.010)\end{array}$ & $\begin{array}{l}-0.112^{* *} \\
(0.047)\end{array}$ & $\begin{array}{l}0.068^{*} \\
(0.039)\end{array}$ & $\begin{array}{l}-0.024 \\
(0.033)\end{array}$ \\
\hline Number of Observations & 2732 & 2726 & 2726 & 2726 & 2726 & 2726 & 2726 \\
\hline Mean of Dep. Var. (Control) & 2.063 & 0.534 & 0.376 & 0.023 & 0.687 & 0.152 & 0.164 \\
\hline R-squared & 0.033 & 0.039 & 0.018 & 0.012 & 0.034 & 0.028 & 0.020 \\
\hline$P$-value for the test $Q=T T$ & 0.414 & 0.982 & 0.978 & 0.439 & 0.947 & 0.967 & 0.064 \\
\hline $\mathrm{P}$-value for the test $\mathrm{Q}=\mathrm{C}$ & 0.765 & 0.209 & 0.585 & 0.505 & 0.910 & 0.704 & 0.854 \\
\hline $\mathrm{P}$-value for the test $\mathrm{Q}=\mathrm{C}+$ & 0.732 & 0.894 & 0.700 & 0.060 & 0.344 & 0.422 & 0.682 \\
\hline P-value for the test TT $=\mathrm{QTT}$ & 0.697 & 0.341 & 0.447 & 0.862 & 0.698 & 0.946 & 0.705 \\
\hline $\mathrm{P}$-value for the test $\mathrm{C}=\mathrm{QC}$ & 0.887 & 0.405 & 0.488 & 0.678 & 0.898 & 0.770 & 0.342 \\
\hline P-value for the test $\mathrm{C}+=\mathrm{QC}+$ & 0.892 & 0.691 & 0.580 & 0.085 & 0.609 & 0.681 & 0.685 \\
\hline P-value for the test that treatments are all equal & 0.897 & 0.466 & 0.878 & 0.657 & 0.969 & 0.923 & 0.255 \\
\hline
\end{tabular}

Notes: Data from endline survey. Sample restricted to girls who were administered endline survey in person. Estimates from an OLS regression. Standard errors clustered at school level. * Significance at $10 \%$ level. ${ }^{* *}$ Significance at $5 \%$ level. ${ }^{* * *}$ Significance at $1 \%$ level. All regressions include region dummies and the same school-level controls as in Table 2. 
Table 5

Impacts on Childbearing and Dropout.

\begin{tabular}{|c|c|c|c|c|c|c|c|c|c|c|c|c|}
\hline & $(1)$ & $(2)$ & (3) & $(4)$ & (5) & (6) & (7) & $(8)$ & (9) & $(10)$ & $(11)$ & $(12)$ \\
\hline & \multicolumn{4}{|c|}{ Has Started childbearing ${ }^{\mathrm{a}}$} & \multicolumn{4}{|c|}{ Currently Pregnant } & \multicolumn{4}{|c|}{ Dropped out of school } \\
\hline In-Class Quiz Only (Q) & $\begin{array}{l}-0.031 \\
(0.019)\end{array}$ & $\begin{array}{l}-0.029^{*} \\
(0.017)\end{array}$ & $\begin{array}{l}-0.023 \\
(0.017)\end{array}$ & $\begin{array}{l}-0.032^{*} \\
(0.018)\end{array}$ & $\begin{array}{l}-0.013 \\
(0.013)\end{array}$ & $\begin{array}{l}-0.014 \\
(0.012)\end{array}$ & $\begin{array}{l}-0.013 \\
(0.012)\end{array}$ & $\begin{array}{l}-0.019^{*} \\
(0.011)\end{array}$ & $\begin{array}{l}-0.001 \\
(0.015)\end{array}$ & $\begin{array}{l}0.006 \\
(0.015)\end{array}$ & $\begin{array}{l}0.009 \\
(0.015)\end{array}$ & $\begin{array}{l}-0.003 \\
(0.013)\end{array}$ \\
\hline Teacher Training Only (TT) & $\begin{array}{l}-0.046^{* *} \\
(0.021)\end{array}$ & $\begin{array}{l}-0.044^{* *} \\
(0.019)\end{array}$ & $\begin{array}{l}-0.038^{* *} \\
(0.018)\end{array}$ & $\begin{array}{l}-0.050^{* * *} \\
(0.019)\end{array}$ & $\begin{array}{l}-0.018 \\
(0.012)\end{array}$ & $\begin{array}{l}-0.020^{*} \\
(0.011)\end{array}$ & $\begin{array}{l}-0.019^{*} \\
(0.011)\end{array}$ & $\begin{array}{l}-0.018 \\
(0.011)\end{array}$ & $\begin{array}{l}-0.031^{*} \\
(0.016)\end{array}$ & $\begin{array}{l}-0.027^{*} \\
(0.015)\end{array}$ & $\begin{array}{l}-0.025 \\
(0.016)\end{array}$ & $\begin{array}{l}-0.022^{*} \\
(0.013)\end{array}$ \\
\hline In-Class Quiz + Teacher Training (QTT) & $\begin{array}{l}-0.016 \\
(0.021)\end{array}$ & $\begin{array}{l}-0.017 \\
(0.017)\end{array}$ & $\begin{array}{l}-0.013 \\
(0.017)\end{array}$ & $\begin{array}{l}-0.022 \\
(0.018)\end{array}$ & $\begin{array}{l}-0.001 \\
(0.014)\end{array}$ & $\begin{array}{l}-0.002 \\
(0.012)\end{array}$ & $\begin{array}{l}0.000 \\
(0.012)\end{array}$ & $\begin{array}{l}-0.003 \\
(0.012)\end{array}$ & $\begin{array}{l}-0.013 \\
(0.016)\end{array}$ & $\begin{array}{l}-0.016 \\
(0.015)\end{array}$ & $\begin{array}{l}-0.014 \\
(0.015)\end{array}$ & $\begin{array}{l}-0.006 \\
(0.014)\end{array}$ \\
\hline Consultant Only (C) & $\begin{array}{l}-0.033^{*} \\
(0.020)\end{array}$ & $\begin{array}{l}-0.033^{*} \\
(0.018)\end{array}$ & $\begin{array}{l}-0.031^{*} \\
(0.017)\end{array}$ & $\begin{array}{l}-0.023 \\
(0.018)\end{array}$ & $\begin{array}{l}-0.020^{*} \\
(0.012)\end{array}$ & $\begin{array}{l}-0.022^{*} \\
(0.011)\end{array}$ & $\begin{array}{l}-0.021^{*} \\
(0.011)\end{array}$ & $\begin{array}{l}-0.018 \\
(0.011)\end{array}$ & $\begin{array}{l}-0.028^{*} \\
(0.016)\end{array}$ & $\begin{array}{l}-0.024^{*} \\
(0.014)\end{array}$ & $\begin{array}{l}-0.023 \\
(0.014)\end{array}$ & $\begin{array}{l}-0.015 \\
(0.013)\end{array}$ \\
\hline In-Class Quiz + Consultant (QC) & $\begin{array}{l}-0.036^{*} \\
(0.019)\end{array}$ & $\begin{array}{l}-0.031^{*} \\
(0.018)\end{array}$ & $\begin{array}{l}-0.027 \\
(0.017)\end{array}$ & $\begin{array}{l}-0.025 \\
(0.017)\end{array}$ & $\begin{array}{l}-0.022^{* *} \\
(0.011)\end{array}$ & $\begin{array}{l}-0.022^{*} \\
(0.011)\end{array}$ & $\begin{array}{l}-0.020^{*} \\
(0.011)\end{array}$ & $\begin{array}{l}-0.018 \\
(0.011)\end{array}$ & $\begin{array}{l}-0.021 \\
(0.015)\end{array}$ & $\begin{array}{l}-0.015 \\
(0.014)\end{array}$ & $\begin{array}{l}-0.012 \\
(0.015)\end{array}$ & $\begin{array}{l}-0.005 \\
(0.013)\end{array}$ \\
\hline Consultant Plus Only (C+) & $\begin{array}{l}-0.033 \\
(0.022)\end{array}$ & $\begin{array}{l}-0.029 \\
(0.020)\end{array}$ & $\begin{array}{l}-0.025 \\
(0.019)\end{array}$ & $\begin{array}{l}-0.023 \\
(0.020)\end{array}$ & $\begin{array}{l}-0.025^{* *} \\
(0.011)\end{array}$ & $\begin{array}{l}-0.026^{* *} \\
(0.011)\end{array}$ & $\begin{array}{l}-0.025^{* *} \\
(0.011)\end{array}$ & $\begin{array}{l}-0.023^{* *} \\
(0.011)\end{array}$ & $\begin{array}{l}-0.014 \\
(0.017)\end{array}$ & $\begin{array}{l}-0.013 \\
(0.015)\end{array}$ & $\begin{array}{l}-0.011 \\
(0.015)\end{array}$ & $\begin{array}{l}-0.002 \\
(0.013)\end{array}$ \\
\hline In-Class Quiz + Consultant Plus (QC+) & $\begin{array}{l}-0.018 \\
(0.027)\end{array}$ & $\begin{array}{l}-0.025 \\
(0.020)\end{array}$ & $\begin{array}{l}-0.027 \\
(0.020)\end{array}$ & $\begin{array}{l}-0.031 \\
(0.020)\end{array}$ & $\begin{array}{l}-0.020 \\
(0.012)\end{array}$ & $\begin{array}{l}-0.022^{*} \\
(0.012)\end{array}$ & $\begin{array}{l}-0.022^{*} \\
(0.012)\end{array}$ & $\begin{array}{l}-0.024^{* *} \\
(0.012)\end{array}$ & $\begin{array}{l}-0.016 \\
(0.017)\end{array}$ & $\begin{array}{l}-0.018 \\
(0.016)\end{array}$ & $\begin{array}{l}-0.019 \\
(0.016)\end{array}$ & $\begin{array}{l}-0.012 \\
(0.014)\end{array}$ \\
\hline Number of Observations & 2892 & 2892 & 2892 & 2732 & 2891 & 2891 & 2891 & 2728 & 2905 & 2905 & 2905 & 2732 \\
\hline Mean of Dep. Var. (Control) & 0.095 & 0.095 & 0.095 & 0.095 & 0.036 & 0.036 & 0.036 & 0.036 & 0.071 & 0.071 & 0.071 & 0.071 \\
\hline R-squared & 0.115 & 0.144 & 0.192 & 0.180 & 0.048 & 0.059 & 0.070 & 0.047 & 0.293 & 0.305 & 0.319 & 0.065 \\
\hline P-value for the test $Q=T T$ & 0.385 & 0.391 & 0.354 & 0.314 & 0.698 & 0.602 & 0.602 & 0.931 & 0.037 & 0.019 & 0.017 & 0.093 \\
\hline P-value for the test $Q=C$ & 0.898 & 0.830 & 0.615 & 0.610 & 0.526 & 0.471 & 0.452 & 0.878 & 0.055 & 0.026 & 0.016 & 0.290 \\
\hline P-value for the test $Q=C+$ & 0.931 & 0.999 & 0.902 & 0.626 & 0.248 & 0.224 & 0.219 & 0.572 & 0.397 & 0.200 & 0.180 & 0.908 \\
\hline P-value for the test $\mathrm{TT}=\mathrm{QTT}$ & 0.101 & 0.124 & 0.142 & 0.121 & 0.187 & 0.119 & 0.118 & 0.178 & 0.199 & 0.426 & 0.450 & 0.158 \\
\hline$P$-value for the test $C=Q C$ & 0.850 & 0.948 & 0.799 & 0.926 & 0.861 & 0.971 & 0.930 & 0.985 & 0.630 & 0.491 & 0.405 & 0.374 \\
\hline P-value for the test $\mathrm{C}+=\mathrm{QC}+$ & 0.614 & 0.877 & 0.922 & 0.708 & 0.628 & 0.689 & 0.786 & 0.984 & 0.894 & 0.718 & 0.573 & 0.417 \\
\hline P-value for the test that treatments are all equal & 0.787 & 0.848 & 0.864 & 0.759 & 0.539 & 0.436 & 0.406 & 0.604 & 0.424 & 0.307 & 0.238 & 0.512 \\
\hline
\end{tabular}

Notes: Data from endline survey. Estimates from an OLS regression. Standard errors clustered at school level. * Significance at $10 \%$ level. ${ }^{* *}$ Significance at $5 \%$ level. *** Significance at $1 \%$ level. School-level control variables as in Table 2. Individual-level control variables: Dummies for female guardian's education level, age and age squared.

a "Has started childbearing" is a dummy equal to 1 if ever pregnant. 


\subsection{Pregnancy}

Table 5 presents the results on pregnancy. We consider two pregnancy outcomes: whether a girl reports having ever been pregnant at the time of the endline ("Has started childbearing", which is equivalent to "ever pregnant"), and whether she reports being pregnant at the time of the endline ("currently pregnant"). We find that all interventions decreased the incidence of pregnancy and cannot reject that their impacts are the same (the p-value for the test that treatments' impacts are all equal is always above 0.75 ). Some of the estimates are noisy, which is not surprising given that we do not have baseline individual controls and the outcomes of interest are still fairly rare (the control group means are $9.5 \%$ for having started chilbearing and 3.6\% for currently pregnant). The impacts on current pregnancy are generally smaller than the impact on the incidence of pregnancy: all treatments pooled together, we find a $2.9 \%$ point decrease in "ever pregnant" and a $1.8 \%$ point decrease in "currently pregnant" (Appendix A Table A5 Panel A Columns 3-4). Assuming that only women who got pregnant at least 2 months prior would report being pregnant, it means that the impact distributes over time as follows: a 1.1\% point decrease in the first three months after the intervention, and a 1.8\% point decrease in the next seven months (those who got pregnant in the last 2 months don't know yet). The average "impact per month" is thus $0.36 \%$ point decrease in the first three months and $0.26 \%$ point decrease later on. The impact seems more important in the short term, but still present in the longer term. ${ }^{13}$ The Consultant interventions ( $\mathrm{C}$ and $\mathrm{C}+$ ) appear to have a weaker effect on having started childbearing, but a stronger effect on current pregnancies, which may be due to the fact that these interventions took place a bit later, hence only 49 weeks prior to the endline survey on average. However, there is no statistically significant differences in effectiveness between the teacher delivery mode and the consultant delivery mode, and between the $A B C$ message and $A B C+$ sugar daddy message (Appendix A Table A5 Panel C). Overall, the magnitude of the effects on childbearing is large - of the order of a 25-48 percent drop depending on the program and specification, and 31\% decrease when we pool all treatments together (Appendix A Table A5 Panel A) - and in line with the 28 percent decrease observed over a similar time period by Dupas (2011) in Kenya.

In this study, trainings and quizzes were given to both male and female students. The treatment effects on pregnancy thus incorporate the effects on the males. However, our data show that grade 8 girls tend to choose older partners than the boys in their grade. In fact, as shown in Table 1, partners are on average 20-year old at baseline and 21-year old at endline, which means four years older on average than the female students. The distribution of partners' age shows that $93 \%$ of girls' last partners are 18 or more (this proportion goes up to $98.5 \%$ among girls who have ever been pregnant). Therefore, most partners are not in the same class as the female students and the treatment effects likely can't be explained by the boys in the school getting treated.

Table 5 also presents results on dropout. The coefficients are negative for most of the treatment arms, though few are significant, and the magnitude in percentage points is smaller than the results on pregnancy, possibly because some of those currently pregnant have not yet had to dropout. It also appears to be the case that girls who are pregnant or have given birth are not barred from attending school, in contrast to the norms that prevailed in Kenya at the time of Dupas (2011) and Duflo et al. (2015). ${ }^{14}$

Overall, the fact that the $\mathrm{C}+$ intervention did not have a higher impact on actual pregnancies than the other interventions suggests that in the Cameroon context, the basic "ABC" message may be sufficient. There is no clear added benefit to the relative risk message focused on sponsors. In fact, the $A B C$ message seems to have already permeated the environment enough that just reminding students of it through an interactive Quiz seems sufficient to make risks salient and deter risky sexual activity for at least 9 months.

Appendix A Table A6 shows the FDR-adjusted q-values for the ten key outcomes of interest. Most impact estimates retain significance at $10 \%$ or less.

\subsection{Heterogeneity: rural vs. urban}

The study took place in two different contexts: the South and West regions are mostly rural while Yaoundé is purely urban. There are stark differences between these two contexts, with slightly more HIV education in Yaoundé than in rural areas on the one hand, and much riskier sexual behavior in rural areas on the other hand. For instance, $23 \%$ of girls in the pure control group have been exposed to HIV education led by external consultants in Yaoundé, whereas 16\% in the South and West regions have (this can be seen in Table 6, comparing "control group means" across the two panels). Conversely, teen pregnancy is much more frequent in rural areas (12\% versus $4 \%$ in Yaoundé), and the same was true for school dropouts ( $9 \%$ versus 3\% in Yaoundé), and sexual activity (34\% versus 17\%). Note also that sexual activity is much riskier: while 35\% of girls having had sex in the last 12 months declare that they had unprotected sex (0.06/0.17), this ratio is as high as $68 \%$

\footnotetext{
12 The Quiz included the question: “According to you, can mosquitoes transmit HIV?”. As shown earlier in Table 1, a large majority (63\%) of those who answered the question said "yes".

${ }^{13}$ Measurement errors do not account for the smaller effects on current pregnancy as all girls who declare that they are currently pregnant also declare that they have been pregnant but one girl who is missing.

${ }^{14}$ We also collected information on marital status. Marriage is a very rare outcome in the sample (only $2.2 \%$ of girls report being ever married at endline, see Table 1) and we do not see any significant impacts of any of the treatments on marriage.
} 
Table 6

Heterogeneity by rural/urban

\begin{tabular}{|c|c|c|c|c|c|c|c|c|c|c|c|}
\hline Panel A. Rural & $\begin{array}{l}(1) \\
\text { Has endline data }\end{array}$ & $\begin{array}{l}\text { (2) } \\
\text { Total Time } \\
\text { (minutes) of HIV } \\
\text { education in past } 12 \\
\text { months }\end{array}$ & $\begin{array}{l}\text { (3) } \\
\text { Had HIV education } \\
\text { led by external } \\
\text { consultants }\end{array}$ & $\begin{array}{l}(4) \\
\text { Has started } \\
\text { childbearing }\end{array}$ & $\begin{array}{l}\text { (5) } \\
\text { Currently } \\
\text { pregnant }\end{array}$ & $\begin{array}{l}\text { (6) } \\
\text { Dropped out }\end{array}$ & $\begin{array}{l}\text { (7) } \\
\text { Personal plan to } \\
\text { avoid HIV infection } \\
\text { in coming year: } \\
\text { Number of } \\
\text { strategies listed }\end{array}$ & $\begin{array}{l}\text { (8) } \\
\text { Plans to abstain }\end{array}$ & $\begin{array}{l}(9) \\
\text { Plans to use } \\
\text { condoms }\end{array}$ & $\begin{array}{l}(10) \\
\text { Knowledge } \\
\text { Index }\end{array}$ & $\begin{array}{l}\text { (11) } \\
\text { Perceived Risk } \\
\text { Index }\end{array}$ \\
\hline In-Class Quiz Only (Q) & $\begin{array}{l}-0.040 \\
(0.033)\end{array}$ & $\begin{array}{l}12.879 \\
(13.794)\end{array}$ & $\begin{array}{l}0.179^{* *} \\
(0.071)\end{array}$ & $\begin{array}{l}-0.037^{*} \\
(0.022)\end{array}$ & $\begin{array}{l}-0.015 \\
(0.017)\end{array}$ & $\begin{array}{l}-0.002 \\
(0.019)\end{array}$ & $\begin{array}{l}-0.230 \\
(0.186)\end{array}$ & $\begin{array}{l}0.073 \\
(0.054)\end{array}$ & $\begin{array}{l}-0.112^{*} \\
(0.062)\end{array}$ & $\begin{array}{l}0.035 \\
(0.047)\end{array}$ & $\begin{array}{l}0.103^{*} \\
(0.057)\end{array}$ \\
\hline Teacher Training Only (TT) & $\begin{array}{l}0.022 \\
(0.029)\end{array}$ & $\begin{array}{l}101.669^{* * *} \\
(20.806)\end{array}$ & $\begin{array}{l}0.080 \\
(0.066)\end{array}$ & $\begin{array}{l}-0.052^{* *} \\
(0.025)\end{array}$ & $\begin{array}{l}-0.030^{*} \\
(0.015)\end{array}$ & $\begin{array}{l}-0.039^{*} \\
(0.021)\end{array}$ & $\begin{array}{l}-0.169 \\
(0.207)\end{array}$ & $\begin{array}{l}0.056 \\
(0.059)\end{array}$ & $\begin{array}{l}-0.084 \\
(0.072)\end{array}$ & $\begin{array}{l}0.118^{* *} \\
(0.049)\end{array}$ & $\begin{array}{l}-0.029 \\
(0.058)\end{array}$ \\
\hline $\begin{array}{l}\text { In-Class Quiz + Teacher } \\
\text { Training (QTT) }\end{array}$ & -0.023 & $87.974^{* * *}$ & $0.181^{* *}$ & -0.012 & 0.000 & -0.020 & -0.172 & $0.128^{* *}$ & $-0.109^{*}$ & $0.108^{* *}$ & 0.037 \\
\hline & $(0.032)$ & $(18.601)$ & $(0.071)$ & $(0.024)$ & $(0.017)$ & $(0.019)$ & $(0.189)$ & $(0.052)$ & $(0.059)$ & $(0.053)$ & $(0.059)$ \\
\hline Consultant Only (C) & $\begin{array}{l}-0.000 \\
(0.030)\end{array}$ & $\begin{array}{l}72.604^{* * *} \\
(15.319)\end{array}$ & $\begin{array}{l}0.543^{* * * *} \\
(0.070)\end{array}$ & $\begin{array}{l}-0.051^{* *} \\
(0.022)\end{array}$ & $\begin{array}{l}-0.028^{*} \\
(0.015)\end{array}$ & $\begin{array}{l}-0.043^{* *} \\
(0.018)\end{array}$ & $\begin{array}{l}-0.200 \\
(0.175)\end{array}$ & $\begin{array}{l}0.144^{* * * *} \\
(0.049)\end{array}$ & $\begin{array}{l}-0.103^{*} \\
(0.061)\end{array}$ & $\begin{array}{l}0.084^{*} \\
(0.046)\end{array}$ & $\begin{array}{l}0.016 \\
(0.056)\end{array}$ \\
\hline $\begin{array}{l}\text { In-Class Quiz + Consultant } \\
\text { (QC) }\end{array}$ & 0.002 & $83.360^{* * *}$ & $0.590^{* * *}$ & -0.034 & $-0.028^{*}$ & -0.021 & -0.287 & 0.020 & -0.086 & $0.104^{*}$ & 0.051 \\
\hline & $(0.032)$ & $(14.642)$ & $(0.061)$ & $(0.024)$ & $(0.015)$ & $(0.019)$ & $(0.190)$ & $(0.053)$ & $(0.060)$ & $(0.057)$ & $(0.055)$ \\
\hline Consultant Plus Only (C+) & $\begin{array}{l}-0.017 \\
(0.030)\end{array}$ & $\begin{array}{l}69.375 * * * \\
(16.620)\end{array}$ & $\begin{array}{l}0.586^{* * * *} \\
(0.067)\end{array}$ & $\begin{array}{l}-0.038 \\
(0.027)\end{array}$ & $\begin{array}{l}-0.037^{* *} \\
(0.015)\end{array}$ & $\begin{array}{l}-0.029 \\
(0.021)\end{array}$ & $\begin{array}{l}-0.234 \\
(0.188)\end{array}$ & $\begin{array}{l}0.091^{*} \\
(0.051)\end{array}$ & $\begin{array}{l}-0.083 \\
(0.059)\end{array}$ & $\begin{array}{l}0.147^{* * * *} \\
(0.049)\end{array}$ & $\begin{array}{l}-0.017 \\
(0.062)\end{array}$ \\
\hline $\begin{array}{l}\text { In-Class Quiz + Consultant } \\
\text { Plus (QC+) }\end{array}$ & 0.017 & $94.693^{* * *}$ & $0.542^{* * *}$ & -0.039 & -0.021 & -0.025 & -0.273 & 0.048 & -0.071 & $0.148^{* * *}$ & -0.023 \\
\hline & $(0.029)$ & $(18.978)$ & $(0.073)$ & $(0.027)$ & $(0.017)$ & $(0.021)$ & $(0.182)$ & $(0.050)$ & $(0.057)$ & $(0.054)$ & $(0.061)$ \\
\hline $\begin{array}{l}\text { Number of Observations } \\
\text { Mean of Dep. Var. (Control) }\end{array}$ & $\begin{array}{l}2214 \\
0.925\end{array}$ & $\begin{array}{l}1813 \\
38.648\end{array}$ & $\begin{array}{l}1914 \\
0.162\end{array}$ & $\begin{array}{l}2054 \\
0.123\end{array}$ & $\begin{array}{l}2053 \\
0.046\end{array}$ & $\begin{array}{l}2068 \\
0.090\end{array}$ & $\begin{array}{l}1914 \\
2.018\end{array}$ & $\begin{array}{l}1908 \\
0.500\end{array}$ & $\begin{array}{l}1908 \\
0.671\end{array}$ & $\begin{array}{l}1855 \\
-0.064\end{array}$ & $\begin{array}{l}1864 \\
-0.010\end{array}$ \\
\hline $\begin{array}{l}\text { R-squared } \\
\text { Panel B. Urban (Yaounde) }\end{array}$ & 0.052 & 0.123 & 0.239 & 0.204 & 0.064 & 0.319 & 0.053 & 0.079 & 0.081 & 0.051 & 0.045 \\
\hline In-Class Quiz Only (Q) & $\begin{array}{l}-0.022 \\
(0.045)\end{array}$ & $\begin{array}{l}-7.171 \\
(18.417)\end{array}$ & $\begin{array}{l}-0.007 \\
(0.092)\end{array}$ & $\begin{array}{l}0.016 \\
(0.028)\end{array}$ & $\begin{array}{l}-0.019 \\
(0.018)\end{array}$ & $\begin{array}{l}0.013 \\
(0.021)\end{array}$ & $\begin{array}{l}-0.688^{* * *} \\
(0.190)\end{array}$ & $\begin{array}{l}-0.009 \\
(0.077)\end{array}$ & $\begin{array}{l}-0.186^{* *} \\
(0.080)\end{array}$ & $\begin{array}{l}-0.055 \\
(0.064)\end{array}$ & $\begin{array}{l}0.212^{* *} \\
(0.093)\end{array}$ \\
\hline Teacher Training Only (TT) & $\begin{array}{l}0.014 \\
(0.047)\end{array}$ & $\begin{array}{l}-21.707 \\
(14.842)\end{array}$ & $\begin{array}{l}-0.092 \\
(0.094)\end{array}$ & $\begin{array}{l}-0.002 \\
(0.022)\end{array}$ & $\begin{array}{l}-0.001 \\
(0.013)\end{array}$ & $\begin{array}{l}0.003 \\
(0.020)\end{array}$ & $\begin{array}{l}-0.489 \\
(0.295)\end{array}$ & $\begin{array}{l}-0.009 \\
(0.071)\end{array}$ & $\begin{array}{l}-0.192^{* *} \\
(0.093)\end{array}$ & $\begin{array}{l}0.041 \\
(0.061)\end{array}$ & $\begin{array}{l}-0.134 \\
(0.123)\end{array}$ \\
\hline $\begin{array}{l}\text { In-Class Quiz + Teacher } \\
\text { Training (QTT) }\end{array}$ & 0.000 & 0.919 & -0.126 & 0.003 & 0.007 & 0.030 & -0.224 & 0.007 & -0.066 & $0.170^{* *}$ & -0.156 \\
\hline & $(0.052)$ & $(17.671)$ & $(0.099)$ & $(0.018)$ & $(0.014)$ & $(0.020)$ & $(0.254)$ & $(0.067)$ & $(0.089)$ & $(0.083)$ & $(0.128)$ \\
\hline Consultant Only (C) & $\begin{array}{l}-0.025 \\
(0.051)\end{array}$ & $\begin{array}{l}18.382 \\
(24.827)\end{array}$ & $\begin{array}{l}0.218^{* *} \\
(0.108)\end{array}$ & $\begin{array}{l}0.040 \\
(0.025)\end{array}$ & $\begin{array}{l}-0.003 \\
(0.016)\end{array}$ & $\begin{array}{l}0.023 \\
(0.023)\end{array}$ & $\begin{array}{l}-0.527^{* *} \\
(0.205)\end{array}$ & $\begin{array}{l}0.061 \\
(0.074)\end{array}$ & $\begin{array}{l}-0.144 \\
(0.097)\end{array}$ & $\begin{array}{l}0.003 \\
(0.063)\end{array}$ & $\begin{array}{l}0.126 \\
(0.096)\end{array}$ \\
\hline $\begin{array}{l}\text { In-Class Quiz + Consultant } \\
\text { (QC) }\end{array}$ & -0.023 & -20.684 & 0.092 & 0.003 & 0.001 & 0.011 & $-0.547^{* *}$ & $0.142^{* *}$ & $-0.190^{* *}$ & 0.060 & 0.134 \\
\hline & $(0.041)$ & $(14.757)$ & $(0.091)$ & $(0.021)$ & $(0.016)$ & $(0.021)$ & $(0.209)$ & $(0.065)$ & $(0.089)$ & $(0.060)$ & $(0.133)$ \\
\hline Consultant Plus Only $\left(\mathrm{C}^{+}\right)$ & $\begin{array}{l}-0.007 \\
(0.045)\end{array}$ & $\begin{array}{l}9.920 \\
(18.687)\end{array}$ & $\begin{array}{l}0.184^{*} \\
(0.104)\end{array}$ & $\begin{array}{l}0.037 \\
(0.023)\end{array}$ & $\begin{array}{l}0.008 \\
(0.016)\end{array}$ & $\begin{array}{l}0.034^{*} \\
(0.020)\end{array}$ & $\begin{array}{l}-0.552^{* * *} \\
(0.200)\end{array}$ & $\begin{array}{l}-0.061 \\
(0.072)\end{array}$ & $\begin{array}{l}-0.081 \\
(0.094)\end{array}$ & $\begin{array}{l}0.064 \\
(0.054)\end{array}$ & $\begin{array}{l}-0.092 \\
(0.132)\end{array}$ \\
\hline $\begin{array}{l}\text { In-Class Quiz + Consultant } \\
\text { Plus (QC+) }\end{array}$ & -0.046 & $35.653^{*}$ & $0.213^{* *}$ & 0.008 & $-0.019^{*}$ & -0.014 & $-0.525^{* *}$ & -0.043 & $-0.171^{* *}$ & $0.212^{* * * *}$ & 0.082 \\
\hline & $(0.042)$ & $(18.719)$ & $(0.095)$ & $(0.027)$ & $(0.011)$ & $(0.019)$ & $(0.213)$ & $(0.064)$ & $(0.084)$ & $(0.062)$ & $(0.095)$ \\
\hline Number of Observations & 940 & 805 & 818 & 838 & 838 & 837 & 818 & 818 & 818 & 810 & 806 \\
\hline Mean of Dep. Var. (Control) & 0.891 & 43.017 & 0.225 & 0.041 & 0.016 & 0.033 & 2.150 & 0.600 & 0.717 & 0.126 & 0.030 \\
\hline $\begin{array}{l}\text { R-squared } \\
\text {. val. (cis }\end{array}$ & 0.023 & 0.090 & 0.139 & 0.158 & 0.174 & 0.368 & 0.149 & 0.119 & 0.090 & 0.101 & 0.083 \\
\hline
\end{tabular}

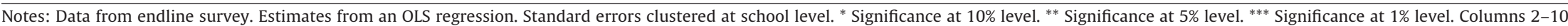
include school-level and individual-level controls as in Table 5. Columns 7-10: sample restricted to individuals surveyed in person at endline. 
in rural areas $(0.23 / 0.34)$. Rural areas seem thus clearly in greater need for HIV education than urban areas, but this need is more often unmet there.

Table 6 presents the treatment effects for the main outcomes of interests, estimated separately for rural and urban areas. Strikingly, all of the results are concentrated in rural areas: all results are found similar in Panel A (rural), but absent in Yaoundé (Panel B). The "first-stage" is itself weaker in Yaoundé: respondents do not report significantly higher time exposure to HIV education in treatment groups in Yaoundé, except for one of the 7 treatments. There is no decrease in unprotected sex incidence in Yaoundé, where the base rate is 6\% compared to $23 \%$ in rural areas. Similarly, there is no decrease in pregnancy in Yaoundé, where, as mentioned above, the base rate of childbearing is only $4 \%$ compared to $12 \%$ in rural areas. If anything, we see a positive and significant (at 10\%) impact on pregnancy for the Consultant Only group - but this is the only significant coefficient on outcomes in Yaoundé, suggesting that it may be due to sampling variation (the sample size is smaller for Yaoundé since more than two thirds of the sample is rural).

In conclusion, HIV education proved to be more effective at reducing risky behaviors in areas where behaviors are most at risk. While this result may seem obvious ex-post, it is not granted that individuals who most need a program are the most responsive to that program, as barriers may be more profound and difficult to overcome.

\section{Discussion and conclusions}

We conducted a randomized experiment with teenage schoolgirls in both urban and rural areas of Cameroon. Our results suggest that simple and short HIV prevention interventions can be effective at reducing the incidence of teen pregnancy in rural areas, where teenage pregnancy is common, but not in urban Yaoundé, where teenagers are more exposed to information under the status quo and experience much lower rates of unwanted pregnancy.

The main finding from this experiment is that all four interventions seemed to be quite effective. This finding is important as it suggests that teenage behavior can be responsive to interventions that are fairly "light touch" and do not involve any incentive, empowerment or cash transfer component. It also shows that teenage response to educational interventions does not vary so much with the format and identity of the messenger - female external consultants providing one single session, or male school staff providing several sessions. This paper thus provides evidence that risky sexual behaviors are not (only) adaptive responses to structural socio-economic conditions, nor the consequence of irrepressible impulses.

The second important finding of this experiment is that providing accurate and credible information is not a prerequisite. The identity of the messenger does not appear to matter, and in fact the presence of a messenger itself may not be key. Indeed, arguably the most surprising result is the large impact of the In-Class Quiz. This intervention was not particularly "lighter touch" in terms of time (the activity took approximately one hour, the same time investment as the consultants intervention). But it was lighter touch in terms of content: the In-Class Quiz did not convey proper information or explanations on risks associated with unprotected sex and avoidance strategies. It just spurred girls into an active review of their beliefs and behavior. Bidwell et al. (2016) hypothesize the strong survey effects in their political knowledge study may come from the survey priming respondents to seek out information. In our case, this explanation is unlikely to drive the In-Class Quiz impact as it is not consistent with the absence of impacts on knowledge shown in Table 3: would the survey have encouraged girls to look for information on HIV and reproductive health, their general knowledge would have increased relative to the control group. More plausibly, the survey acted as an awakening tool and a prompt to make a plan (which may include some discussions with friends or relatives). When answering questions about their knowledge and behavior, the survey primed the topic and revealed to students their own ignorance, inattention, and lack of decisions. The impact could be long lasting since perceived risks have been persistently adjusted upward, and the plan once formed can stick. Suggestive evidence of this mechanism is the fact that the In-Class Quiz did not increase HIV knowledge, but increased perceived risks and the proportion of girls who plan to only abstain, and decreased unprotected sex and pregnancies. This intervention, as the others, worked in part by making girls home in on a concrete plan with regards to their future sexual behavior, consistently with the literature suggesting that plan-making helps people overcome several psychological barriers to follow through (Gollwitzer and Sheeran 2006).

The In-Class Quiz may also have an impact on preferences as questions in the In-Class Quiz may convene some information about socially desirable/undesirable behaviors: even if the In-Class Quiz does not indicate what behavior is desirable and undesirable, respondents may infer some information from the questions (wrongly or rightly) and change weights put on certain behaviors in their utility function. For instance, asking girls whether they used condom during their first intercourse may increase the view that using condom is socially desirable and induce a higher weight on using condoms in their utility function. As we don't measure preferences, we cannot provide such evidence. The fact that the In-Class Quiz was groupadministered in class also means that students were aware of each other's reactions to it - e.g. the fact that students took the In-Class Quiz seriously and did not joke or deride the activity publicly could have changed students second order beliefs, and influenced behaviors further through that channel: e.g. if others take these risks seriously then maybe I should too. One final question is whether the In-Class Quiz effect is simply an Hawthorne effect. Having to fill a questionnaire about one's own behavior can make one feel observed, but the questionnaire was anonymous and this was very clearly mentioned to students. What's more the pure effect of being observed (by the researchers) would likely have faded quickly since no new interaction with the research team happened for many months after the quiz took place. Rather, we think that the In-Class Quiz made it salient to students that there was a gap between actual and desired behavior. Of course, the desired behavior may be the behavior dictated by society, itself an "observer". 
The third important result is that the identity of the messenger, teachers versus outside professionals, does not seem to matter. In another context, George et al. (2012) also found that community members were as efficient as outside professionals at educating the population about water arsenic issues and reducing arsenic exposure. In Cameroon, students proved responsive to both school staff interventions and consultant interventions, which indicates that teachers do not suffer from lack of legitimacy or confidence. Appendix A Table A5 Panel C shows that total time in HIV education was similar under the teacher and consultant delivery modes, ${ }^{15}$ and the fact that consultants used videos does not seem to be important as behaviors chandeg the same way in both delivery modes.

Finally, it is interesting that in the present context the specific message studied in Dupas (2011) (the higher risk associated with sex with older men, "sugar daddies") does not seem to be particularly important above and beyond the more traditional $A B C$ prevention message. We see two explanations for this finding. First, all four interventions discussed condom use as a key strategy rather than exhorting abstinence, while Dupas (2011) compared the sugar daddy risk message with an abstinenceonly curriculum. The lack of effects of the "sugar daddy risk" intervention over that of the ABC message may suggest that discussing condom use is the key strategy. Along these lines, the simple ABC message could possibly have been as effective at reducing teenage pregnancy in the Kenyan context as the sugar daddy risk message, had it been acceptable (to this day, the official HIV prevention curriculum for primary schools in Kenya do not discuss condoms). A second explanation is that the role of cross-generational sex in fueling the disease may have been less important in Cameroon than in Kenya. Girls are equally misinformed of the age gradient in HIV risk, but one important difference is that the HIV rate is lower in Cameroon: according to the Demographic and Health Surveys, the infection rate among men aged 25-29 was 3\% in 2011, whereas in Kenya it was 7.3 percent in 2003 and 6.5 percent in 2008/2009. Moreover, condom use is also higher among men 25-49 in Cameroon than in Kenya. According to the Demographic and Health Surveys, among men aged 25-29 with at least two sexual partners in the past 12 months, the share who used a condom at last intercourse was $52 \%$ in Cameroon in early 2011 (about 6 months after the end of our study) vs. only 40\% in Kenya in 2008/2009 (4-5 years after the Kenya study). For older age groups, the gap was even larger: $31 \%$ vs. $16 \%$ for age group 30-39, and 16\% vs. 9\% for age group 40-49. Most importantly, data from our Table 1 Column 1 and from Dupas (2011)'s Table 1 shows that cross-generational sex seems less prevalent in Cameroon than in Kenya. Indeed, while a similar proportion of girls declare having had sex in our Cameroon sample and in Dupas (2011)'s sample (22\% versus 21\%), only 4\% declare ever had a partner over 25 in our sample while $16 \%$ in the Kenyan sample. ${ }^{16}$ If cross-generational sex is likely an important factor in the spread of HIV in both countries since the infection rate among younger women is considerably larger than that of younger men in both cases, this issue may thus be less crucial in Cameroon than in Kenya.

Such interventions can be implemented very cheaply, making them highly cost-effective: our interventions all cost about the same (around $\$ 300$ per class in today's dollars, which amounts to around $\$ 13$ per female student). With an average of 3 pregnancies averted for 100 students treated, the cost per pregnancy averted is just above $\$ 430$. For similar interventions, the cost per averted pregnancy was lower in Dupas (2011) (US\$100) because the cost of the program was lower (the facilitators were paid a regular salary and not honorariums). Given the large impacts on teenage pregnancy and the relatively low cost of the interventions, it is important for future research to replicate these interventions with the scope to study impacts on HIV.

\section{Appendix A.}

\footnotetext{
15 In fact, teachers provided a larger number of sessions but shorter ones as shown in Table 2 columns 2-3

16 In Dupas (2011), the exact statistic is the share reporting age difference with male partner >10 years. Given that girls are on average 15-year-old in both samples, it should be very close to the share having ever had a partner over 25 .
} 
Table A1

School Characteristics and Balance check.

\begin{tabular}{|c|c|c|c|c|c|c|c|c|c|c|c|}
\hline & $\begin{array}{l}(1) \\
\text { Private }\end{array}$ & $\begin{array}{l}(2) \\
\text { Vocational }\end{array}$ & $\begin{array}{l}\text { (3) } \\
\text { Attached to } \\
\text { High school }\end{array}$ & $\begin{array}{l}(4) \\
\text { Student/ } \\
\text { teacher ratio }\end{array}$ & $\begin{array}{l}(5) \\
\text { Female/ male } \\
\text { ratio }\end{array}$ & $\begin{array}{l}(6) \\
\text { National 8th } \\
\text { grade exam } \\
\text { pass rate }\end{array}$ & $\begin{array}{l}(7) \\
\text { Girls' } \\
\text { Absenteeism } \\
\text { rate }\end{array}$ & $\begin{array}{l}\text { (8) } \\
\text { Absenteeism } \\
\text { due to } \\
\text { pregnancy }\end{array}$ & $\begin{array}{l}(9) \\
\text { Urban } \\
\text { (Yaoundé) }\end{array}$ & $\begin{array}{l}(10) \\
\text { South }\end{array}$ & $\begin{array}{l}(11) \\
\text { Endline survey } \\
\text { self- } \\
\text { administered }\end{array}$ \\
\hline Mean of Dep. Var. (Control) & 0.400 & 0.050 & 0.300 & 22.927 & 0.502 & 0.399 & 0.152 & 0.008 & 0.350 & 0.125 & 0.525 \\
\hline In-Class Quiz Only (Q) & $\begin{array}{l}-0.100 \\
(0.105)\end{array}$ & $\begin{array}{l}0.100 \\
(0.067)\end{array}$ & $\begin{array}{l}0.025 \\
(0.105)\end{array}$ & $\begin{array}{l}0.462 \\
(3.059)\end{array}$ & $\begin{array}{l}0.002 \\
(0.022)\end{array}$ & $\begin{array}{l}0.006 \\
(0.038)\end{array}$ & $\begin{array}{l}0.011 \\
(0.032)\end{array}$ & $\begin{array}{l}0.001 \\
(0.006)\end{array}$ & $\begin{array}{l}-0.075 \\
(0.104)\end{array}$ & $\begin{array}{l}-0.025 \\
(0.071)\end{array}$ & $\begin{array}{l}-0.125 \\
(0.111)\end{array}$ \\
\hline Teacher Training Only (TT) & $\begin{array}{l}-0.125 \\
(0.105)\end{array}$ & $\begin{array}{l}0.150^{* *} \\
(0.067)\end{array}$ & $\begin{array}{l}-0.000 \\
(0.105)\end{array}$ & $\begin{array}{l}0.268 \\
(3.019)\end{array}$ & $\begin{array}{l}0.020 \\
(0.022)\end{array}$ & $\begin{array}{l}0.007 \\
(0.038)\end{array}$ & $\begin{array}{l}0.001 \\
(0.032)\end{array}$ & $\begin{array}{l}0.001 \\
(0.006)\end{array}$ & $\begin{array}{l}-0.025 \\
(0.104)\end{array}$ & $\begin{array}{l}0.000 \\
(0.071)\end{array}$ & $\begin{array}{l}-0.050 \\
(0.111)\end{array}$ \\
\hline \multirow[t]{2}{*}{$\begin{array}{l}\text { In-Class Quiz + Teacher } \\
\text { Training (QTT) }\end{array}$} & -0.075 & 0.025 & 0.050 & 3.543 & 0.005 & -0.009 & -0.044 & 0.001 & -0.075 & -0.050 & -0.025 \\
\hline & $(0.105)$ & $(0.067)$ & $(0.105)$ & (3.001) & $(0.022)$ & $(0.036)$ & $(0.032)$ & $(0.006)$ & $(0.104)$ & $(0.071)$ & $(0.111)$ \\
\hline Consultant Only (C) & $\begin{array}{l}-0.100 \\
(0.105)\end{array}$ & $\begin{array}{l}0.075 \\
(0.067)\end{array}$ & $\begin{array}{l}0.025 \\
(0.105)\end{array}$ & $\begin{array}{l}6.310^{* *} \\
(3.001)\end{array}$ & $\begin{array}{l}-0.020 \\
(0.022)\end{array}$ & $\begin{array}{l}0.033 \\
(0.037)\end{array}$ & $\begin{array}{l}0.024 \\
(0.032)\end{array}$ & $\begin{array}{l}0.007 \\
(0.006)\end{array}$ & $\begin{array}{l}-0.100 \\
(0.104)\end{array}$ & $\begin{array}{l}0.050 \\
(0.071)\end{array}$ & $\begin{array}{l}0.075 \\
(0.111)\end{array}$ \\
\hline \multirow[t]{2}{*}{$\begin{array}{l}\text { In-Class Quiz + Consultant } \\
\text { (QC) }\end{array}$} & -0.144 & 0.001 & 0.008 & -1.084 & -0.005 & 0.018 & -0.032 & -0.002 & -0.017 & -0.048 & -0.166 \\
\hline & $(0.106)$ & $(0.068)$ & $(0.106)$ & (3.019) & $(0.022)$ & $(0.036)$ & $(0.032)$ & $(0.006)$ & $(0.105)$ & $(0.072)$ & $(0.112)$ \\
\hline Consultant Plus Only (C+) & $\begin{array}{l}-0.092 \\
(0.106)\end{array}$ & $\begin{array}{l}0.027 \\
(0.068)\end{array}$ & $\begin{array}{l}-0.018 \\
(0.106)\end{array}$ & $\begin{array}{l}2.485 \\
(3.039)\end{array}$ & $\begin{array}{l}0.002 \\
(0.022)\end{array}$ & $\begin{array}{l}0.049 \\
(0.037)\end{array}$ & $\begin{array}{l}-0.012 \\
(0.033)\end{array}$ & $\begin{array}{l}0.004 \\
(0.007)\end{array}$ & $\begin{array}{l}-0.042 \\
(0.105)\end{array}$ & $\begin{array}{l}-0.048 \\
(0.072)\end{array}$ & $\begin{array}{l}-0.166 \\
(0.112)\end{array}$ \\
\hline \multirow[t]{2}{*}{$\begin{array}{l}\text { In-Class Quiz + Consultant } \\
\text { Plus (QC+) }\end{array}$} & -0.025 & 0.025 & 0.025 & -0.105 & 0.000 & -0.006 & -0.002 & 0.010 & -0.025 & 0.025 & 0.050 \\
\hline & $(0.105)$ & $(0.067)$ & $(0.105)$ & $(3.001)$ & $(0.022)$ & $(0.037)$ & $(0.032)$ & $(0.006)$ & $(0.104)$ & $(0.071)$ & $(0.111)$ \\
\hline Number of Observations & 318 & 318 & 318 & 311 & 318 & 258 & 314 & 314 & 318 & 318 & 318 \\
\hline R-squared & 0.009 & 0.027 & 0.002 & 0.031 & 0.011 & 0.016 & 0.022 & 0.017 & 0.005 & 0.012 & 0.031 \\
\hline P-value for the test $Q=T T$ & 0.812 & 0.457 & 0.812 & 0.949 & 0.418 & 0.975 & 0.775 & 0.940 & 0.631 & 0.726 & 0.501 \\
\hline$P$-value for the test $Q=C$ & 1.000 & 0.710 & 1.000 & 0.054 & 0.325 & 0.484 & 0.686 & 0.375 & 0.810 & 0.294 & 0.073 \\
\hline P-value for the test $\mathrm{Q}=\mathrm{C}+$ & 0.942 & 0.281 & 0.685 & 0.509 & 0.979 & 0.273 & 0.492 & 0.721 & 0.755 & 0.748 & 0.715 \\
\hline $\begin{array}{l}\text { P-value for the test } \\
\text { TT = QTT }\end{array}$ & 0.634 & 0.064 & 0.634 & 0.273 & 0.518 & 0.671 & 0.156 & 0.923 & 0.631 & 0.484 & 0.823 \\
\hline $\mathrm{P}$-value for the test $\mathrm{C}=\mathrm{QC}$ & 0.680 & 0.276 & 0.870 & 0.014 & 0.494 & 0.681 & 0.082 & 0.155 & 0.427 & 0.173 & 0.032 \\
\hline $\begin{array}{l}\text { P-value for the test } \\
\mathrm{C}+=\mathrm{QC}+\end{array}$ & 0.524 & 0.977 & 0.685 & 0.389 & 0.925 & 0.149 & 0.767 & 0.340 & 0.869 & 0.309 & 0.055 \\
\hline $\begin{array}{l}\text { P-value for the test that } \\
\text { treatments are all equal }\end{array}$ & 0.955 & 0.286 & 0.998 & 0.178 & 0.748 & 0.718 & 0.360 & 0.561 & 0.980 & 0.713 & 0.161 \\
\hline
\end{tabular}

Notes: Unit of observation is a school. Estimates from an OLS regression. ${ }^{*}$ Significance at $10 \%$ level. ${ }^{* *}$ Significance at $5 \%$ level. ${ }^{* * *}$ Significance at $1 \%$ level. 
Table A2

Attrition.

\begin{tabular}{|c|c|c|c|c|}
\hline & $(1)$ & $(2)$ & $(3)$ & $(4)$ \\
\hline & \multicolumn{2}{|c|}{ Has endline data (in-person or through proxy) } & \multicolumn{2}{|c|}{ Surveyed in-person at endline } \\
\hline \multirow[t]{2}{*}{ In-Class Quiz Only (Q) } & -0.025 & -0.028 & -0.045 & $-0.052^{*}$ \\
\hline & $(0.028)$ & $(0.027)$ & $(0.029)$ & $(0.028)$ \\
\hline \multirow[t]{2}{*}{ Teacher Training Only (TT) } & 0.033 & 0.027 & 0.031 & 0.018 \\
\hline & $(0.023)$ & $(0.025)$ & $(0.026)$ & $(0.026)$ \\
\hline \multirow[t]{2}{*}{ In-Class Quiz + Teacher Training (QTT) } & 0.005 & 0.000 & 0.005 & -0.004 \\
\hline & $(0.026)$ & $(0.027)$ & $(0.026)$ & $(0.026)$ \\
\hline \multirow[t]{2}{*}{ Consultant Only (C) } & 0.005 & 0.004 & 0.015 & 0.010 \\
\hline & $(0.026)$ & $(0.026)$ & $(0.027)$ & $(0.026)$ \\
\hline \multirow[t]{2}{*}{ In-Class Quiz + Consultant (QC) } & 0.016 & 0.002 & 0.004 & -0.010 \\
\hline & $(0.025)$ & $(0.025)$ & $(0.028)$ & $(0.027)$ \\
\hline \multirow[t]{2}{*}{ Consultant Plus Only (C+) } & 0.009 & 0.001 & 0.012 & -0.003 \\
\hline & $(0.027)$ & $(0.026)$ & $(0.029)$ & $(0.029)$ \\
\hline \multirow[t]{2}{*}{ In-Class Quiz + Consultant Plus (QC+) } & 0.006 & 0.006 & -0.004 & -0.007 \\
\hline & $(0.024)$ & $(0.024)$ & $(0.027)$ & $(0.026)$ \\
\hline Number of Observations & 3154 & 3154 & 3154 & 3154 \\
\hline Mean of Dep. Var. (Control) & 0.913 & 0.913 & 0.864 & 0.864 \\
\hline R-squared & 0.009 & 0.031 & 0.004 & 0.018 \\
\hline $\mathrm{P}$-value for the test $\mathrm{Q}=\mathrm{TT}$ & 0.024 & 0.025 & 0.008 & 0.011 \\
\hline P-value for the test $\mathrm{Q}=\mathrm{C}$ & 0.285 & 0.215 & 0.041 & 0.027 \\
\hline P-value for the test $\mathrm{Q}=\mathrm{C}+$ & 0.242 & 0.256 & 0.067 & 0.112 \\
\hline $\mathrm{P}$-value for the test $\mathrm{TT}=\mathrm{QTT}$ & 0.242 & 0.284 & 0.314 & 0.396 \\
\hline P-value for the test $\mathrm{C}=\mathrm{QC}$ & 0.631 & 0.931 & 0.711 & 0.447 \\
\hline P-value for the test $\mathrm{C}+=\mathrm{QC}+$ & 0.898 & 0.833 & 0.581 & 0.892 \\
\hline P-value for the test that treatments are all equal & 0.438 & 0.507 & 0.254 & 0.286 \\
\hline School-level controls & & $\mathrm{Y}$ & & $\mathrm{Y}$ \\
\hline
\end{tabular}

Notes: Estimates from an OLS regression. Standard errors clustered at school level. ${ }^{*}$ Significance at $10 \%$ level. ${ }^{* *}$ Significance at $5 \%$ level. ${ }^{* * *}$ Significance at $1 \%$ level.

Table A3

Impacts on Perceived HIV Risk.

\begin{tabular}{|c|c|c|c|c|c|c|}
\hline & $\begin{array}{l}\text { (1) } \\
\text { Perceived HIV } \\
\text { prevalence in } \\
\text { Cameroon } \\
\text { (proportion of } \\
\text { infected } \\
\text { individuals in the } \\
\text { population, } 0-100 \text { ) }\end{array}$ & $\begin{array}{l}\text { (2) } \\
\text { Perceived chance } \\
\text { (out of 10) of } \\
\text { getting infected if } \\
\text { engages in } \\
\text { unprotected sex }\end{array}$ & $\begin{array}{l}\text { (3) } \\
\text { Perceived chance } \\
\text { (out of 10) of } \\
\text { getting infected if } \\
\text { engages in } \\
\text { unprotected sex } \\
\text { with multiple } \\
\text { partners }\end{array}$ & $\begin{array}{l}(4) \\
\text { Perceived chance } \\
\text { (out of 10) of } \\
\text { getting infected } \\
\text { by kissing } \\
\text { somebody }\end{array}$ & $\begin{array}{l}\text { (5) } \\
\text { Perceived chance } \\
\text { (out of 10) of } \\
\text { getting infected if } \\
\text { engages in } \\
\text { protected sex with } \\
\text { partner } 10 \text { or more } \\
\text { years older }\end{array}$ & $\begin{array}{l}(6) \\
\text { Perceived Risk } \\
\text { Index }^{\mathrm{a}}\end{array}$ \\
\hline In-Class Quiz Only (Q) & $\begin{array}{l}2.21 \\
(2.54)\end{array}$ & $\begin{array}{l}0.56^{* *} \\
(0.27)\end{array}$ & $\begin{array}{l}0.20 \\
(0.15)\end{array}$ & $\begin{array}{l}0.13 \\
(0.17)\end{array}$ & $\begin{array}{l}0.40 \\
(0.27)\end{array}$ & $\begin{array}{l}0.118^{* *} \\
(0.047)\end{array}$ \\
\hline Teacher Training Only (TT) & $\begin{array}{l}-1.04 \\
(2.28)\end{array}$ & $\begin{array}{l}0.06 \\
(0.32)\end{array}$ & $\begin{array}{l}-0.35^{*} \\
(0.20)\end{array}$ & $\begin{array}{l}-0.01 \\
(0.18)\end{array}$ & $\begin{array}{l}-0.03 \\
(0.28)\end{array}$ & $\begin{array}{l}-0.056 \\
(0.056)\end{array}$ \\
\hline $\begin{array}{l}\text { In-Class Quiz + Teacher } \\
\text { Training (QTT) }\end{array}$ & $\begin{array}{l}3.33 \\
(2.27)\end{array}$ & $\begin{array}{l}0.14 \\
(0.29)\end{array}$ & $\begin{array}{l}-0.05 \\
(0.18)\end{array}$ & $\begin{array}{l}-0.04 \\
(0.20)\end{array}$ & $\begin{array}{l}-0.32 \\
(0.24)\end{array}$ & $\begin{array}{l}0.000 \\
(0.052)\end{array}$ \\
\hline Consultant Only (C) & $\begin{array}{l}3.02 \\
(2.09)\end{array}$ & $\begin{array}{l}-0.07 \\
(0.28)\end{array}$ & $\begin{array}{l}-0.25 \\
(0.18)\end{array}$ & $\begin{array}{l}0.24 \\
(0.17)\end{array}$ & $\begin{array}{l}0.20 \\
(0.26)\end{array}$ & $\begin{array}{l}0.037 \\
(0.048)\end{array}$ \\
\hline $\begin{array}{l}\text { In-Class Quiz + Consultant } \\
\text { (QC) }\end{array}$ & $\begin{array}{l}6.55^{* * *} \\
(2.33)\end{array}$ & $\begin{array}{l}-0.09 \\
(0.32)\end{array}$ & $\begin{array}{l}-0.24 \\
(0.18)\end{array}$ & $\begin{array}{l}0.20 \\
(0.18)\end{array}$ & $\begin{array}{l}0.24 \\
(0.25)\end{array}$ & $\begin{array}{l}0.064 \\
(0.054)\end{array}$ \\
\hline Consultant Plus Only (C+) & $\begin{array}{l}0.67 \\
(2.24)\end{array}$ & $\begin{array}{l}-0.19 \\
(0.29)\end{array}$ & $\begin{array}{l}-0.13 \\
(0.18)\end{array}$ & $\begin{array}{l}-0.06 \\
(0.18)\end{array}$ & $\begin{array}{l}-0.33 \\
(0.25)\end{array}$ & $\begin{array}{l}-0.052 \\
(0.055)\end{array}$ \\
\hline $\begin{array}{l}\text { In-Class Quiz + Consultant } \\
\text { Plus (QC+) }\end{array}$ & $\begin{array}{l}2.33 \\
(2.28)\end{array}$ & $\begin{array}{l}-0.34 \\
(0.29)\end{array}$ & $\begin{array}{l}-0.16 \\
(0.17)\end{array}$ & $\begin{array}{l}-0.04 \\
(0.19)\end{array}$ & $\begin{array}{l}0.46^{*} \\
(0.25)\end{array}$ & $\begin{array}{l}0.006 \\
(0.050)\end{array}$ \\
\hline Number of Observations & 2689 & 2726 & 2725 & 2730 & 2722 & 2670 \\
\hline Mean of Dep. Var. (Control) & 47.240 & 6.075 & 8.989 & 1.132 & 2.324 & 0.004 \\
\hline R-squared & 0.069 & 0.024 & 0.019 & 0.029 & 0.029 & 0.034 \\
\hline P-value for the test $\mathrm{Q}=\mathrm{TT}$ & 0.194 & 0.105 & 0.006 & 0.410 & 0.149 & 0.002 \\
\hline P-value for the test $\mathrm{Q}=\mathrm{C}$ & 0.729 & 0.017 & 0.022 & 0.486 & 0.471 & 0.082 \\
\hline P-value for the test $\mathrm{Q}=\mathrm{C}+$ & 0.528 & 0.010 & 0.066 & 0.277 & 0.008 & 0.002 \\
\hline P-value for the test & 0.056 & 0.794 & 0.194 & 0.878 & 0.296 & 0.332 \\
\hline
\end{tabular}

$\mathrm{TT}=\mathrm{QTT}$ 
Table A3 (Continued)

\begin{tabular}{|c|c|c|c|c|c|c|}
\hline & $\begin{array}{l}\text { (1) } \\
\text { Perceived HIV } \\
\text { prevalence in } \\
\text { Cameroon } \\
\text { (proportion of } \\
\text { infected } \\
\text { individuals in the } \\
\text { population, } 0-100 \text { ) }\end{array}$ & $\begin{array}{l}\text { (2) } \\
\text { Perceived chance } \\
\text { (out of 10) of } \\
\text { getting infected if } \\
\text { engages in } \\
\text { unprotected sex }\end{array}$ & $\begin{array}{l}\text { (3) } \\
\text { Perceived chance } \\
\text { (out of 10) of } \\
\text { getting infected if } \\
\text { engages in } \\
\text { unprotected sex } \\
\text { with multiple } \\
\text { partners }\end{array}$ & $\begin{array}{l}\text { (4) } \\
\text { Perceived chance } \\
\text { (out of 10) of } \\
\text { getting infected } \\
\text { by kissing } \\
\text { somebody }\end{array}$ & $\begin{array}{l}\text { (5) } \\
\text { Perceived chance } \\
\text { (out of 10) of } \\
\text { getting infected if } \\
\text { engages in } \\
\text { protected sex with } \\
\text { partner } 10 \text { or more } \\
\text { years older }\end{array}$ & $\begin{array}{l}\text { (6) } \\
\text { Perceived Risk } \\
\text { Index }^{a}\end{array}$ \\
\hline $\mathrm{P}$-value for the test $\mathrm{C}=\mathrm{QC}$ & 0.105 & 0.930 & 0.989 & 0.829 & 0.878 & 0.601 \\
\hline $\begin{array}{l}\text { P-value for the test } \\
\qquad \mathrm{C}+=\mathrm{QC}+\end{array}$ & 0.447 & 0.623 & 0.862 & 0.927 & 0.003 & 0.323 \\
\hline $\begin{array}{l}\text { P-value for the test that } \\
\text { treatments are all equal }\end{array}$ & 0.050 & 0.039 & 0.075 & 0.404 & 0.006 & 0.014 \\
\hline
\end{tabular}

Notes: Data from endline survey. Sample restricted to girls who were administered endline survey in person. Estimates from an OLS regression. Standard errors clustered at school level. * Significance at $10 \%$ level. ${ }^{* *}$ Significance at $5 \%$ level. ${ }^{* * *}$ Significance at $1 \%$ level. All regressions include region dummies and the same school-level controls as in Table 2. ${ }^{a}$ The Perceived Risk Index is the average of the z-scores of the variables in columns (1) to (5). Each z-score is standardized mean $=0$, std. $\operatorname{dev}=1$, for the control group.

Table A4

Impacts on Pregnancy Outcomes using a Probit specification.

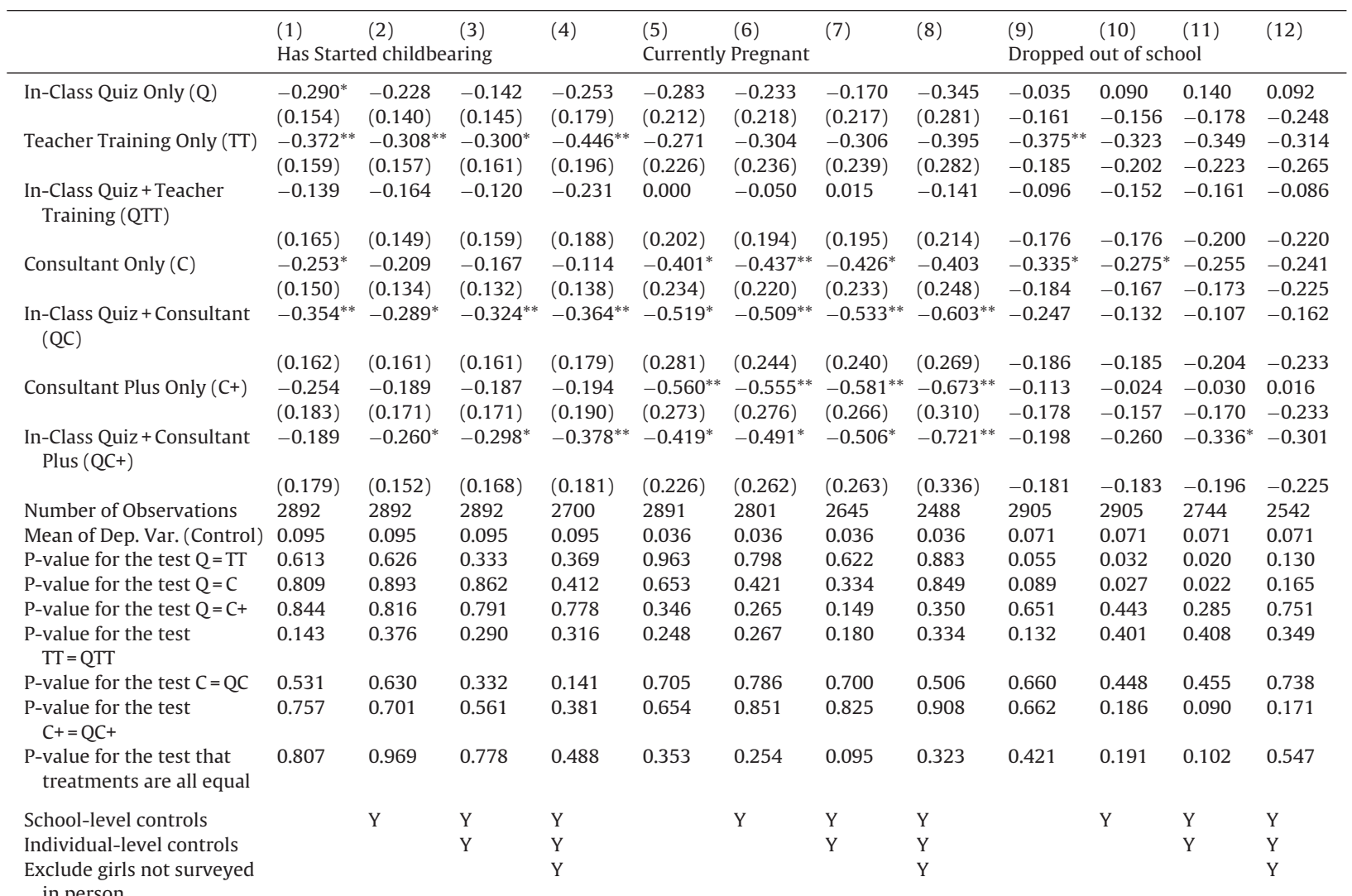

in person

Notes: Data from endline survey. Estimates from a probit regression. Standard errors clustered at school level. * Significance at $10 \%$ level. ${ }^{* *}$ Significance at $5 \%$ level. *** Significance at $1 \%$ level. School-level control variables as in Table 2 . Individual-level control variables: Dummies for female guardian's education level, age and age squared. 


\begin{tabular}{|c|c|c|c|c|c|c|c|c|c|c|}
\hline & $\begin{array}{l}(1) \\
\text { Total Time } \\
\text { (minutes) of HIV } \\
\text { education in past } \\
12 \text { months }\end{array}$ & $\begin{array}{l}\text { (2) } \\
\text { Had HIV } \\
\text { education led by } \\
\text { external } \\
\text { consultants }\end{array}$ & $\begin{array}{l}\text { (3) } \\
\text { Has started } \\
\text { child-bearing }\end{array}$ & $\begin{array}{l}\text { (4) } \\
\text { Currently } \\
\text { pregnant }\end{array}$ & $\begin{array}{l}\text { (5) } \\
\text { Dropped out }\end{array}$ & $\begin{array}{l}(6) \\
\text { Personal plan to } \\
\text { avoid HIV infection } \\
\text { in coming year: } \\
\text { Number of } \\
\text { strategies listed }\end{array}$ & $\begin{array}{l}(7) \\
\text { Plans to } \\
\text { abstain }\end{array}$ & $\begin{array}{l}(8) \\
\text { Plans to use } \\
\text { condoms }\end{array}$ & $\begin{array}{l}\text { (9) } \\
\text { Knowledge } \\
\text { Index }\end{array}$ & $\begin{array}{l}\text { (10) } \\
\text { Perceived } \\
\text { Risk Index }\end{array}$ \\
\hline \multicolumn{11}{|l|}{ Panel A. Any Intervention } \\
\hline \multirow[t]{2}{*}{$\begin{array}{l}\text { Any Intervention (Q, TT, C, } \\
\text { C+, QTT, QC, QC+) }\end{array}$} & $53.253^{* * *}$ & $0.297^{* * *}$ & $-0.029^{* *}$ & $-0.018^{*}$ & -0.009 & $-0.294^{* *}$ & $0.060^{*}$ & $-0.109^{* * *}$ & $0.101^{* * *}$ & 0.020 \\
\hline & $(9.528)$ & $(0.045)$ & $(0.014)$ & $(0.009)$ & $(0.011)$ & $(0.131)$ & $(0.032)$ & $(0.038)$ & $(0.028)$ & $(0.037)$ \\
\hline R-squared & 0.091 & 0.097 & 0.179 & 0.045 & 0.063 & 0.043 & 0.070 & 0.070 & 0.069 & 0.028 \\
\hline \multicolumn{11}{|c|}{ Panel B. Educational Trainings versus In-Class Quiz } \\
\hline In-Class Quiz Only (Q) & $\begin{array}{l}6.194 \\
(12.256)\end{array}$ & $\begin{array}{l}0.127^{* *} \\
(0.059)\end{array}$ & $\begin{array}{l}-0.031^{*} \\
(0.018)\end{array}$ & $\begin{array}{l}-0.019 * \\
(0.011)\end{array}$ & $\begin{array}{l}-0.003 \\
(0.013)\end{array}$ & $\begin{array}{l}-0.354^{* *} \\
(0.142)\end{array}$ & $\begin{array}{l}0.045 \\
(0.048)\end{array}$ & $\begin{array}{l}-0.126^{* * *} \\
(0.048)\end{array}$ & $\begin{array}{l}0.006 \\
(0.040)\end{array}$ & $\begin{array}{l}0.120^{* *} \\
(0.047)\end{array}$ \\
\hline \multirow[t]{2}{*}{$\begin{array}{l}\text { Any Educational Training } \\
(\mathrm{TT}, \mathrm{C}, \mathrm{C}+)\end{array}$} & $57.108^{* * * *}$ & $0.325^{* * *}$ & $-0.031^{* *}$ & $-0.020^{* *}$ & -0.013 & $-0.295^{* *}$ & $0.067^{*}$ & $-0.110^{* * *}$ & $0.099^{* * *}$ & -0.018 \\
\hline & (10.917) & $(0.052)$ & $(0.015)$ & $(0.010)$ & $(0.012)$ & $(0.138)$ & $(0.035)$ & $(0.041)$ & $(0.030)$ & $(0.042)$ \\
\hline \multirow[t]{2}{*}{$\begin{array}{l}\text { In-Class Quiz + Any } \\
\text { Educational Training } \\
\text { (QTT, QC, QC+) }\end{array}$} & $64.913^{* * *}$ & $0.325^{* * *}$ & $-0.026^{*}$ & -0.015 & -0.008 & $-0.274^{* *}$ & $0.058^{*}$ & $-0.102^{* *}$ & $0.135^{* * *}$ & 0.024 \\
\hline & $(10.930)$ & $(0.052)$ & $(0.015)$ & $(0.010)$ & $(0.012)$ & $(0.138)$ & $(0.035)$ & $(0.041)$ & $(0.033)$ & $(0.042)$ \\
\hline R-squared & 0.110 & 0.113 & 0.179 & 0.045 & 0.064 & 0.043 & 0.071 & 0.070 & 0.077 & 0.034 \\
\hline $\begin{array}{l}\text { P-value for the test } Q=\text { Any } \\
\text { Educ } T\end{array}$ & 0.000 & 0.000 & 0.990 & 0.894 & 0.306 & 0.509 & 0.605 & 0.678 & 0.008 & 0.001 \\
\hline $\begin{array}{l}\text { P-value for the test Any } \\
\text { Educ } T=Q+\text { Any Educ } T\end{array}$ & 0.436 & 0.996 & 0.596 & 0.382 & 0.455 & 0.774 & 0.757 & 0.781 & 0.195 & 0.218 \\
\hline $\begin{array}{l}\text { P-value for the test } \\
Q=Q+\text { Any Educ } T\end{array}$ & 0.000 & 0.000 & 0.682 & 0.578 & 0.637 & 0.383 & 0.762 & 0.521 & 0.001 & 0.019 \\
\hline $\begin{array}{l}\text { P-value for the test that } \\
\text { treatments are all equal }\end{array}$ & 0.000 & 0.000 & 0.845 & 0.664 & 0.533 & 0.680 & 0.865 & 0.813 & 0.003 & 0.003 \\
\hline \multicolumn{11}{|c|}{ Panel C. Consultant delivery mode and Sugar Daddy message Added-Values } \\
\hline \multirow[t]{2}{*}{$\begin{array}{l}\text { Any Intervention ( } \mathrm{Q}, \mathrm{TT}, \mathrm{C} \text {, } \\
\left.\mathrm{C}^{+}, \mathrm{QTT}, \mathrm{QC}, \mathrm{QC}+\right)\end{array}$} & $43.888^{* * *}$ & $0.083^{*}$ & $-0.034^{* *}$ & -0.013 & -0.010 & $-0.251^{*}$ & 0.059 & $-0.113^{* * *}$ & $0.085^{* * *}$ & 0.024 \\
\hline & $(11.137)$ & $(0.048)$ & $(0.015)$ & $(0.010)$ & $(0.011)$ & $(0.141)$ & $(0.036)$ & $(0.042)$ & $(0.032)$ & $(0.042)$ \\
\hline \multirow[t]{2}{*}{$\begin{array}{l}\text { Consultant Delivery Mode } \\
\text { (C, C+, QC, QC+) }\end{array}$} & 10.105 & $0.351^{* * *}$ & 0.010 & -0.004 & 0.000 & -0.067 & 0.031 & -0.004 & -0.010 & 0.029 \\
\hline & (9.955) & $(0.038)$ & $(0.010)$ & $(0.006)$ & $(0.007)$ & $(0.084)$ & $(0.032)$ & $(0.032)$ & $(0.029)$ & $(0.034)$ \\
\hline \multirow[t]{2}{*}{$\begin{array}{l}\text { Sugar Daddy Message (C+, } \\
\text { QC+) }\end{array}$} & 11.016 & 0.013 & -0.003 & -0.006 & 0.003 & -0.012 & $-0.059^{*}$ & 0.020 & $0.075^{* *}$ & $-0.072^{*}$ \\
\hline & $(10.163)$ & $(0.043)$ & $(0.012)$ & $(0.006)$ & $(0.008)$ & $(0.078)$ & $(0.033)$ & $(0.032)$ & $(0.029)$ & (0.039) \\
\hline R-squared & 0.095 & 0.204 & 0.179 & 0.046 & 0.063 & 0.044 & 0.072 & 0.070 & 0.073 & 0.030 \\
\hline $\begin{array}{l}\text { P-value for the test Any } \\
T+\text { Consultant }=0\end{array}$ & 0.000 & 0.000 & 0.126 & 0.088 & 0.387 & 0.022 & 0.015 & 0.007 & 0.026 & 0.223 \\
\hline $\begin{array}{l}\text { P-value for the test Any } \\
\mathrm{T}+\text { Consultant }+ \text { Sugar } \\
\text { Daddy }=0\end{array}$ & 0.000 & 0.000 & 0.108 & 0.022 & 0.572 & 0.018 & 0.410 & 0.022 & 0.000 & 0.663 \\
\hline $\begin{array}{l}\text { Number of Observations in } \\
\text { all panels A, B, C }\end{array}$ & 2618 & 2732 & 2732 & 2728 & 2732 & 2732 & 2726 & 2726 & 2665 & 2670 \\
\hline Mean of Dep. Var. (Control) & 40.142 & 0.184 & 0.095 & 0.036 & 0.071 & 2.063 & 0.534 & 0.687 & 0.002 & 0.004 \\
\hline
\end{tabular}

Notes: Data from endline survey. Estimates from an OLS regression. Standard errors clustered at school level. * Significance at $10 \%$ level. ${ }^{* *}$ Significance at $5 \%$ level. ${ }^{* * *}$ Significance at $1 \%$ level. All regressions include school-level and individual-level controls as in Table 5, and sample restricted to individuals surveyed in person at endline. 
Table A6

Multiple Inference Correction: Naïve p-values and FDR-adjusted sharpened q-values.

\begin{tabular}{|c|c|c|c|c|c|c|c|c|c|c|}
\hline & $\begin{array}{l}(1) \\
\text { Total Time } \\
\text { (minutes) of HIV } \\
\text { education in past } \\
12 \text { months }\end{array}$ & $\begin{array}{l}(2) \\
\text { Had HIV } \\
\text { education led by } \\
\text { external } \\
\text { consultants }\end{array}$ & $\begin{array}{l}\text { (3) } \\
\text { Has started } \\
\text { child-bearing }\end{array}$ & $\begin{array}{l}(4) \\
\text { Currently } \\
\text { pregnant }\end{array}$ & $\begin{array}{l}\text { (5) } \\
\text { Dropped out }\end{array}$ & $\begin{array}{l}(6) \\
\text { Personal plan to } \\
\text { avoid HIV } \\
\text { infection in } \\
\text { coming year: } \\
\text { Number of } \\
\text { strategies listed }\end{array}$ & $\begin{array}{l}(7) \\
\text { Plans to } \\
\text { abstain }\end{array}$ & $\begin{array}{l}(8) \\
\text { Plans to use } \\
\text { condoms }\end{array}$ & $\begin{array}{l}\text { (9) } \\
\text { Knowledge } \\
\text { Index }\end{array}$ & $\begin{array}{l}(10) \\
\text { Perceived } \\
\text { Risk Index }\end{array}$ \\
\hline \multicolumn{11}{|l|}{ Panel A. Individual Treatments } \\
\hline In-Class Quiz Only (Q) & $\begin{array}{l}0.622 \\
{[0.452]}\end{array}$ & $\begin{array}{l}0.046^{* *} \\
{\left[0.088^{*}\right]}\end{array}$ & $\begin{array}{l}0.078^{*} \\
{[0.112]}\end{array}$ & $\begin{array}{l}0.086^{*} \\
{[0.112]}\end{array}$ & $\begin{array}{l}0.819 \\
0[.533]\end{array}$ & $\begin{array}{l}0.014^{* *} \\
{\left[0.049^{* *}\right]}\end{array}$ & $\begin{array}{l}0.37 \\
{[0.269]}\end{array}$ & $\begin{array}{l}0.009^{* * *} \\
{\left[0.049^{* *}\right]}\end{array}$ & $\begin{array}{l}0.869 \\
{[0.533]}\end{array}$ & $\begin{array}{l}0.012^{* *} \\
{\left[0.049^{* *}\right]}\end{array}$ \\
\hline Teacher Training Only (TT) & $\begin{array}{l}0^{* * *} \\
{\left[0.001^{* * *}\right]}\end{array}$ & $\begin{array}{l}0.565 \\
{[.292]}\end{array}$ & $\begin{array}{l}0.008^{* * *} \\
{\left[0.025^{* *}\right]}\end{array}$ & $\begin{array}{l}0.112 \\
{[0.127]}\end{array}$ & $\begin{array}{l}0.088^{*} \\
{[0.121]}\end{array}$ & $\begin{array}{l}0.201 \\
{[0.209]}\end{array}$ & $\begin{array}{l}0.368 \\
{[0.23]}\end{array}$ & $\begin{array}{l}0.043^{* *} \\
{\left[.082^{*}\right]}\end{array}$ & $\begin{array}{l}0.006^{* * *} \\
{\left[0.025^{* *}\right]}\end{array}$ & $\begin{array}{l}0.361 \\
{[0.23]}\end{array}$ \\
\hline \multirow[t]{2}{*}{$\begin{array}{l}\text { In-Class Quiz + Teacher } \\
\text { Training (QTT) }\end{array}$} & $0^{* * *}$ & 0.104 & 0.222 & 0.776 & 0.66 & 0.293 & $0.043^{* *}$ & $0.061^{*}$ & $0.002^{* * *}$ & 0.988 \\
\hline & {$\left[.001^{* * *}\right]$} & [.171] & [.263] & {$[.588]$} & {$[.588]$} & {$[0.265]$} & [0.13] & [0.139] & {$\left[0.01^{* * *}\right]$} & [0.654] \\
\hline Consultant Only (C) & $\begin{array}{l}0^{* * *} \\
{\left[0.001^{* * *}\right]}\end{array}$ & $\begin{array}{l}0^{* * *} \\
{\left[.001^{* * *}\right]}\end{array}$ & $\begin{array}{l}0.19 \\
{[.135]}\end{array}$ & $\begin{array}{l}0.126 \\
{[.118]}\end{array}$ & $\begin{array}{l}0.25 \\
{[.162]}\end{array}$ & $\begin{array}{l}0.022^{* *} \\
{\left[0.028^{* *}\right]}\end{array}$ & $\begin{array}{l}.006^{* * * *} \\
{\left[.017^{* *}\right]}\end{array}$ & $\begin{array}{l}.009^{* * *} \\
{\left[.019^{* *}\right]}\end{array}$ & $\begin{array}{l}0.148 \\
{[0.119]}\end{array}$ & $\begin{array}{l}0.42 \\
{[0.266]}\end{array}$ \\
\hline \multirow[t]{2}{*}{$\begin{array}{l}\text { In-Class Quiz + Consultant } \\
\text { (QC) }\end{array}$} & $0^{* * *}$ & $0^{* * *}$ & 0.15 & 0.116 & 0.682 & $0.052^{*}$ & 0.175 & $.037^{* *}$ & $0.02^{* *}$ & 0.23 \\
\hline & {$\left[.001^{* * *}\right]$} & {$\left[0.001^{* * *}\right]$} & {$[0.12]$} & {$[0.117]$} & {$[0.273]$} & {$[0.079 *]$} & {$[.123]$} & {$\left[.072^{*}\right]$} & {$\left[0.057^{*}\right]$} & {$[0.147]$} \\
\hline Consultant Plus Only (C+) & $\begin{array}{l}0^{* * * *} \\
{\left[0.001^{* * *}\right]}\end{array}$ & $\begin{array}{l}0^{* * * *} \\
{\left[0.001^{* * *}\right]}\end{array}$ & $\begin{array}{l}0.245 \\
{[0.163]}\end{array}$ & $\begin{array}{l}0.03^{* *} \\
{\left[0.047^{* *}\right]}\end{array}$ & $\begin{array}{l}0.902 \\
{[0.539]}\end{array}$ & $\begin{array}{l}0.032^{* *} \\
{\left[0.047^{* *}\right]}\end{array}$ & $\begin{array}{l}0.398 \\
{[.215]}\end{array}$ & $\begin{array}{l}0.071^{*} \\
{\left[0.069^{*}\right]}\end{array}$ & $\begin{array}{l}0^{* * * *} \\
{\left[0.001^{* * *}\right]}\end{array}$ & $\begin{array}{l}0.367 \\
{[0.215]}\end{array}$ \\
\hline \multirow[t]{2}{*}{$\begin{array}{l}\text { In-Class Quiz + Consultant } \\
\text { Plus (QC+) }\end{array}$} & $0^{* * *}$ & $0^{* * *}$ & 0.121 & $0.042^{* *}$ & 0.385 & $0.025^{* *}$ & 0.597 & $0.028^{* *}$ & $0^{* * *}$ & 0.912 \\
\hline & {$\left[0.001^{* * *}\right]$} & {$\left[0.001^{* * *}\right]$} & {$\left[0.076^{*}\right]$} & {$\left[0.052^{*}\right]$} & {$[0.209]$} & {$\left[0.041^{* *}\right]$} & {$[.249]$} & {$\left[0.041^{* *}\right]$} & {$\left[0.001^{* * *}\right]$} & {$[0.377]$} \\
\hline \multicolumn{11}{|c|}{ Panel B. Educational Trainings versus In-Class Quiz } \\
\hline In-Class Quiz Only (Q) & $\begin{array}{l}0.614 \\
{[.444]}\end{array}$ & $\begin{array}{l}0.031^{* *} \\
{\left[0.058^{*}\right]}\end{array}$ & $\begin{array}{l}0.085^{*} \\
{\left[0.097^{*}\right]}\end{array}$ & $\begin{array}{l}0.088^{*} \\
{\left[0.097^{*}\right]}\end{array}$ & $\begin{array}{l}0.826 \\
{[0.539]}\end{array}$ & $\begin{array}{l}0.013^{* *} \\
{\left[.046^{* *}\right]}\end{array}$ & $\begin{array}{l}0.352 \\
{[.252]}\end{array}$ & $\begin{array}{l}0.009^{* * *} \\
{\left[0.046^{* *}\right]}\end{array}$ & $\begin{array}{l}0.875 \\
{[0.539]}\end{array}$ & $\begin{array}{l}0.011^{* *} \\
{\left[0.046^{* *}\right]}\end{array}$ \\
\hline \multirow[t]{2}{*}{$\begin{array}{l}\text { Any Educational Training } \\
\text { (TT, C, C+) }\end{array}$} & $0^{* * *}$ & $0^{* * *}$ & $0.04^{* *}$ & $0.045^{* *}$ & 0.261 & $0.033^{* *}$ & $0.061^{*}$ & $0.008^{* * *}$ & $0.001^{* * *}$ & 0.663 \\
\hline & {$\left[.001^{* * *}\right]$} & {$\left[.001^{* * *}\right]$} & {$\left[0.041^{* *}\right]$} & {$\left[0.041^{* *}\right]$} & {$\left[0.083^{*}\right]$} & {$\left[0.041^{* *}\right]$} & {$\left[0.048^{* *}\right]$} & {$\left[0.015^{* *}\right]$} & {$\left[0.003^{* * *}\right]$} & {$[0.153]$} \\
\hline \multirow{2}{*}{$\begin{array}{l}\text { In-Class Quiz + Any } \\
\text { Educational Training } \\
\text { (QTT, QC, QC+ ) }\end{array}$} & $0^{* * *}$ & $0^{* * *}$ & $0.095^{*}$ & 0.135 & 0.504 & $0.049^{* *}$ & $0.098^{*}$ & $0.014^{* *}$ & $0^{* * *}$ & 0.561 \\
\hline & \multicolumn{10}{|c|}{ Panel C. Consultant delivery mode and Sugar Daddy message Added-Values } \\
\hline \multirow[t]{2}{*}{$\begin{array}{l}\text { Any Intervention (Q, TT, C, } \\
\text { C+, QTT, QC, QC+) }\end{array}$} & $0^{* * *}$ & $0.082^{*}$ & $0.026^{* *}$ & 0.17 & 0.365 & $0.076^{*}$ & 0.102 & $0.008^{* * *}$ & $0.008^{* * *}$ & 0.563 \\
\hline & {$\left[0.001^{* * *}\right]$} & {$\left[0.09^{*}\right]$} & {$\left[0.048^{* *}\right]$} & {$[0.147]$} & [0.171] & {$\left[0.09^{*}\right]$} & [0.096*] & {$\left[0.025^{* *}\right]$} & {$\left[0.025^{* *}\right]$} & [0.204] \\
\hline \multirow[t]{2}{*}{$\begin{array}{l}\text { Consultant Delivery Mode } \\
\left(C, C^{+}, Q C, Q C+\right)\end{array}$} & 0.311 & $0^{* * *}$ & 0.337 & 0.448 & 0.981 & 0.427 & 0.334 & 0.906 & 0.735 & 0.389 \\
\hline & [1] & {$\left[0.001^{* * *}\right]$} & [1] & [1] & [1] & [1] & [1] & [1] & {$[1]$} & {$[1]$} \\
\hline \multirow{2}{*}{$\begin{array}{l}\text { Sugar Daddy Message (C+, } \\
\text { QC }+ \text { ) }\end{array}$} & 0.279 & 0.769 & 0.837 & 0.311 & 0.67 & 0.877 & $0.076^{*}$ & 0.528 & $0.012^{* *}$ & $0.064^{*}$ \\
\hline & {$[0.772]$} & {$[1]$} & [1] & {$[0.772]$} & [1] & [1] & {$[0.296]$} & {$[1]$} & [0.137] & {$[0.296]$} \\
\hline
\end{tabular}

Notes: Data from endline survey. Estimates from an OLS regression. Standard errors clustered at school level. * Significance at $10 \%$ level. ** Significance at $5 \%$ level. *** Significance at $1 \%$ level. All regressions

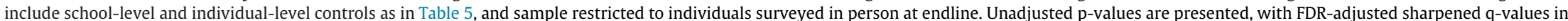
square brackets. Panel A: Same specification as in Tables 2-6. Panel B: Same specification as in Table A5 Panel B. Panel C: Same specification as in Table A5 Panel C. 


\section{Appendix A. Supplementary data}

Supplementary data associated with this article can be found, in the online version, at https://doi.org/10.1016/ j.jebo.2017.10.007.

\section{References}

Anderson, Michael, 2008. Multiple inference and gender differences in the effects of early intervention: a reevaluation of the abecedarian, perry preschool, and early training projects. J. Am. Stat. Assoc. 103 (484), 1481-1495.

Behrman, Jere, Kohler, Hans-Peter, 2012. Sexual transmission of HIV. In: Lomborg, Bjorn (Ed.), RethinkHIV - Smarter Ways to Invest in Ending in Sub-Saharian Africa. Cambridge University Press.

Benjamini, Yoav, Krieger, Abba, Yekutieli, Daniel, 2006. Adaptive linear step-up procedures that control the false discovery rate. Biometrika 93 (3), 491-507.

Bennear, Lori, Tarozzi, Alessandro, Soumya, H.B., Pfaff, Alex, Matin Ahmed, Kazi, van Geen, Lex, 2013. Impact of a randomized controlled trial in arsenic risk communication on household water-source choices in Bangladesh. J. Environ. Econ. Manag. 65 (2), $225-240$.

Bertozzi, Stefano, Padian, Nancy, Wegbreit, Jeny, DeMaria, Lisa, Feldman, Becca, Gayle, Helene, Gold, Julian, Grant, Robert, Isbell, Michael, et al., 2006. HIV/AIDS prevention and treatment, chapter 18. In: Jamison, D.T., Breman, J.G., Measham, A.R. (Eds.), Disease Control Priorities in Developing Countries. , 2nd edition. World Bank, Washington (DC), p. 2006.

Bidwell, Kelly, Casey, Katherine, Glennester, Rachel, 2016. Debates. Voting and Expenditure Re- Sponses to Political Communication. Stanford Graduate School of Business (Working Paper No. 3066).

Canning, David, 2006. The economics of HIV/AIDS in low-income countries: the case for preven- tion. J. Econ. Perspect. 20 (3), 121-142.

Chandon, Pierre, Morwitz, Vicky, Reinartz, Werner, 2005. Do intentions really predict behavior? Self- generated validity effects in survey research. J. Mark. $69,1-14$

Chong, Alberto, Gonzalez-Navarro, Marco, Karlan, Dean, Valdivia, Martin, 2013. Effectiveness and Spillovers of Online Sex Education: Evidence from a Randomized Evaluation in Colombian Public Schools. Yale University, Mimeo.

Chuang, Erica, Dupas, Pascaline, Huillery, Elise, Seban, Juliette, 2017. Sex, Lies, and Measurement. Stanford University, Mimeo.

Datta, Saugato, Burns, Justice, Maughan-Brown, Brendan, Darling, Matthew, Eyal, Katherine, 2015. 'Risking it all for love? Resetting beliefs about HIV risks among low-income South African teens. J. Econ. Behav. Organ. 118, 184-198.

Delavande, Adeline, Kohler, Hans-Peter, 2017. HIV-related expectations and risky sexual Be- havior in Malawi, forthcoming. Rev. Econ. Stud.

de Walque, Damien (Ed.), 2014. Risking Your Health: Causes, Consequences, and Interventions To Prevent Risky Behaviors. World Bank, World Bank.

Dholakia, Utpal, 2010. A critical review of question-behavior effect research. In: Malhotra, N.K. (Ed.), Review of Marketing Research, Vol. 7. Emerald Group Publishing Limited, pp. 145-197.

Duflo, Esther, Dupas, Pascaline, Kremer, Michael, 2015. Education, HIV and early fertility: experimental evidence from Kenya. Am. Econ. Rev. 105 (9), 2757-2797.

Dupas, Pascaline, 2011. Do teenagers respond to HIV risk information? evidence from a field experiment in Kenya. Am. Econ. J. Appl. Econ. 3 (1), 1-36.

Gallant, Melanie, Maticka-Tyndale, Eleanor, 2004. School-Based HIV prevention programmes for african youth. Soc. Sci. Med. 58 (7), $1337-1351$.

George, Christine Marie, Matin Ahmed, Alexander, Slavkovich, Vesna, Singha, Ashit, Levy, Diane, Is-lam, Tariqul, Ahmed, Kazi Matin, Moon-Howard, Joyce, Tarozzi, Alessandro, Liu, Xinhua, Factor-Litvak, Pam, Graziano, Joseph, 2012. A cluster-based randomized controlled trial promoting community participation in arsenic mitigation efforts in Bangladesh. Environ. Health 11, 41

Godlonton, Susan, Alister, Munthali, Rebecca, Thornton, 2016. Responding to risk: circumcision, information, and HIV prevention. Rev. Econ. Stat. 98 (2), $333-349$.

Gollwitzer, Peter M., Sheeran, Parschal, 2006. Implementation intentions and goal achievement: a meta- analysis of effects and processes. Adv. Exp. Soc. Psychol. 38, 69-119.

Gruber, Jonathan, 2001. Risky Behavior Among Youths: An Economic Analysis. University of Chicago Press.

Jamison, Julian, Karlan, Dean, Raffler, Pia, 2013. Mixed method evaluation of a passive health sexual information texting service in Uganda. Inform. Technol. Int. Dev. 9 (3).

Leibowitz, Arleen, Eisen, Marvin, Chow, Winston K., 1986. An economic model of teenage preg- nancy decision-making. Demography 23 (1), 67-77.

Levine, Phillip. B., 2001. The sexual activity and birth-Control use of american teenagers. In: Gruber, Jonathan (Ed.), Risky Behavior Among Youths: An Economic Analysis. University of Chicago Press, pp. 167-218.

Milkman, K.L., Beshears, J., Choi, J.J., Laibson, D., Madrian, B.C., 2011. Using implementation intentions prompts to enhance influenza vaccination rates. Proc. Natl. Acad. Sci. 108, 10415-10420.

Paul-Ebhohimhen, V.A., Poobalan, A., van Teijlingen, E.R., 2008. A systematic review ofschool-based sexual health interventions to prevent STI/HIV in sub-SaharanAfrica. BMC Public Health 8, 4.

Ross, D., Dick, B., Ferguson, J., 2006. Preventing HIV/AIDS in Young People: A Systematic Review of the Evidence from Developing Countries. WHO, Geneva, pp. 2006.

Stango, Victor, Zinman, Jonathan, 2011. Limited and varying consumer attention: evidence from shocks to the salience of bank overdraft fees. Rev. Financ. Stud. 27 (4), 990-1030.

UNAIDS, 2010. Global Report: UNAIDS Report on the global AIDS epidemic 2010.

UNESCO, 2011. UNESCO's strategy for HIV and AIDS. UNESCO Paris, France.June 2011.

World Health Organization (WHO), 2008. Epidemiological Fact Sheet on HIV and AIDS. WHO.

Zwane, A., Zinman, J., Van Dusen, E., Pariente, W., Null, C., Miguel, E., Kremer, M., Karlan, D., Hornbeck, R., Giné, X., Duflo, E., Devoto, F., Crepon, B., Banerjee, A., 2011. Being surveyed can change later behavior and related parameter estimates. Proc. Natl. Acad. Sci. 108 (5), 1821-1826. 